\title{
LA MEDIACIÓN PENAL COMO PROGRAMA DE JUSTICIA RESTAURATIVA EN EL PROCEDIMIENTO PENAL COLOMBIANO*
}

\author{
CRIMINAL MEDIATION AS A RESTORATIVE \\ JUSTICE PROGRAM IN THE COLOMBIAN \\ CRIMINAL PROCEDURE
}

Andrea Catalina Lobo Romero*

\section{Resumen}

La Ley 906 de 2004, actual Código de Procedimiento Penal, incluyó en su Libro VI lo relativo a la justicia restaurativa y señaló, en el art. 521, que sus mecanismos son la conciliación preprocesal, la conciliación en el incidente de reparación integral y la mediación. Este estudio se centra en esta última, pues, aunque el estatuto procesal penal le encargó a la Fiscalía General de la Nación expedir un manual que la desarrollara, más de diez años después de la entrada en vigencia de la norma, esta tarea no se ha cumplido plenamente. La sección doce del Manual de Procedimientos de Fiscalía (2006), si bien se aproxima a ello, no incluye la totalidad de los elementos exigidos por el art. 527 de la Ley 906 de 2004. En la práctica, el uso de la mediación es escaso por parte de los actores del sistema, lo cual limita la aplicación de la justicia restaurativa en materia penal en Colombia. Este artículo expone los principios de la justicia restaurativa, los elementos procesales de la mediación penal señalados por el legislador y, en el mismo, se hacen algunas propuestas en torno a la capacitación de los mediadores en el ordenamiento procesal penal nacional; en este orden de idas, arroja luces sobre cómo puede desarrollarse de manera efectiva este tipo de justicia en asuntos penales.

\section{Palabras claves}

Conflictos derivados del delito. Justicia restaurativa, Manual de mediación, mediación penal, procedimiento penal colombiano.

\begin{abstract}
Law 906 of 2004, current Colombian Code of Criminal Procedure, included in its Book VI the one related to the restorative justice and indicated, in art. 521 , that its mechanisms are the pre-procedural conciliation, the conciliation
\end{abstract}

\footnotetext{
* Trabajo presentado para optar al título de Maestra en Derecho, de la Universidad Sergio Arboleda, Bogotá, Colombia.

** Abogada, Maestra en Derecho, Psicóloga Jurídica y Forense.
} 
in the integral reparation incident and the mediation. This study focuses on the latter, since, although the criminal procedural statute ordered the Attorney General's Office to issue a manual to develop it, ten years after the entry into force of the rule, this task has not been fully implemented. Section twelve of the Manual of Procedures of the Prosecutor's Office (2006), although approaching it, does not include all the elements required by art. 527 of Law 906 of 2004. In practice, the use of mediation is scarce by the actors of the system, which limits the application of restorative justice in criminal matters in Colombia. This article exposes the principles of restorative justice, the procedural elements of criminal mediation pointed out by the legislator and, in the same, some proposals are made concerning the training of mediators in the Colombian criminal procedure; In this order of departure, sheds light on how this type of justice in criminal matters can be effectively developed.

\section{Keywords}

Criminal mediation, Colombian criminal procedure, conflicts derived from crime, Manual of mediation, Restorative justice.

\section{Introducción}

La inclusión de un título denominado 'Justicia Restaurativa' en la Ley 906 de 2004, refleja la intención del legislador de admitir unos elementos distintos a los tradicionalmente aplicados en la resolución de los conflictos derivados de la comisión de un delito o, lo que sería mejor, de aplicar una justicia distinta de la retributiva (Moya \& Reyes, s. f.). Así mismo, reconoce la importancia de las víctimas y de la comunidad dentro de este proceso y admite que, aparte de la consecuencia perjudicial y gravosa de aplicar la fuerza del derecho, puede haber una consecuencia terapéutica o sanadora (Wexler \& Winick, 2005); solo ello explica que el Código de Procedimiento Penal (CPP) señale que "son mecanismos de Justicia Restaurativa la conciliación preprocesal, la conciliación en el incidente de reparación integral y la mediación" (art. 521), permitiendo que la justicia restaurativa se materialice por diferentes vías.

Pese a ello, en el caso de la mediación penal, la figura no ha tenido el alcance esperado; su aplicación impresiona por ser poca, pero tal situación se explica si se tiene en cuenta, entre otras razones, que la Fiscalía General de la Nación tenía la misión de construir un manual que la desarrollara y, sin embargo, más de diez años después de la entrada en vigencia la norma respectiva, esta tarea se ha cumplido tan solo parcialmente, pues el Manual de Procedimientos de la Fiscalía del año 2006, con el cual se quiso dar cumplimiento a lo previsto en el art. 527 CPP, no incluye la manera en que debe hacerse la capacitación y la evaluación de los mediadores y las reglas de conducta relativas al funcionamiento de la figura se limitan a ciertos aspectos. Si a esto se suma que, desde el punto de vista procesal, se advierten obstáculos que dificultan su aplicación, las posibilidades de ponerla en práctica son cada vez más remotas y ello impide hacer efectiva la justicia restaurativa en el tratamiento de la criminalidad.

Es preciso destacar que el art. 518 CPP acogió las definiciones dadas por la Organización de las Naciones Unidas (ONU), a través de la Oficina para las Drogas 
y el Delito (UNODC, por sus siglas en inglés) (2006), que define los programas de justicia restaurativa, así:

[t]odo proceso en el que la víctima y el imputado, acusado o sentenciado (ofensor) participan conjuntamente de forma activa en la resolución de cuestiones derivadas del delito en busca de un resultado restaurativo, con o sin la participación de un facilitador (p. 6).

A renglón seguido, indica que un resultado restaurativo es

[e]l acuerdo encaminado a atender las necesidades y responsabilidades individuales y colectivas de las partes y a lograr la reintegración de la víctima y del infractor en la comunidad en busca de la reparación, la restitución y el servicio a la comunidad (p. 7).

La referencia a la justicia restaurativa hecha por la Ley 906 de 2004 es un buen comienzo para su introducción en el país, pero en ningún caso debe entenderse como un texto acabado, pues, si bien esta última no compite ni niega la retribución (Zehr, 2007), aún falta bastante para que en Colombia se combata el delito desde una perspectiva incluyente, reparadora e integral, que comprenda que las necesidades de las víctimas y de la sociedad en su conjunto van más allá de las indemnizaciones pecuniarias y que los ofensores necesitan mucho más que castigos (Martínez \& Sánchez, 2011).

Este artículo analiza y describe los componentes jurídico-procesales de la mediación penal, en orden a establecer si los presupuestos bajo los cuales fue concebida, se ajustan a los principios de la justicia restaurativa o la hacen viable. En este sentido, se pretende dar respuesta a los siguientes interrogantes: ¿qué es la mediación penal?, ¿cuáles son sus características procesales en Colombia?, ¿riñe con los fines del proceso penal al ocuparse de asuntos que exceden el ius puniendi?, ¿sus requisitos procesales permiten alcanzar la justicia restaurativa?, y ¿quiénes deben ser mediadores para que se cumplan sus fines?

Para absolver los interrogantes planteados, en primer lugar, se hace una descripción de la justicia restaurativa y su filosofía. En un segundo momento, se estudia la figura de la mediación a la luz de las características que se le han otorgado dentro del proceso penal colombiano y la escasa jurisprudencia existente sobre la materia. Para culminar, se ofrece una propuesta relativa al perfil de los mediadores y las temáticas en las que han de encontrarse capacitados.

La investigación se desarrolló siguiendo una metodología analítica-deductiva de las diferentes fuentes de estudio, teniendo como referente el marco normativo en el que la ley procesal ubica la figura.

\section{La justicia restaurativa: definición, origen y características}

La justicia restaurativa es una teoría sobre la justicia que nació en contraposición a otras ideas sobre lo justo, las cuales consideran que, ante la presencia del 
delito, lo importante es ocuparse del delincuente. Es así como se hablaba de justicia vindicativa para hacer referencia al modelo de justicia que imperó bajo la denominada Ley del talión (del latín talis que significa idéntico o semejante), la cual sugería que, ante los agravios, era preciso cobrar venganza; en este caso, no se trataba de una pena equivalente sino de una pena idéntica que el ofendido podía inferir a su ofensor.

Al menos en el plano teórico, las sociedades entendieron que tal forma de administrar justicia era impensable en una organización civilizada, razón por la cual el concepto de justicia vindicativa cedió el paso a una considerada más benevolente: la retributiva, que compaginaba muy bien con los defensores del Estado moderno y su exclusiva potestad para el ejercicio de la acción penal y la imposición de sanciones (Morandé, 2000). Con esta perspectiva, los particulares no pueden tomar la justicia por su propia mano, como ocurre con las vindictas o venganzas, y el Estado es el ente autorizado para causar al victimario un dolor que pague su deuda con la sociedad a quien el Estado representa (Beristain, 1998; Díaz, 2013).

La retribución que el Estado le daba al delincuente se consideraba una respuesta moralmente aceptable a la falta cometida, con independencia de que esta medida produjera o no beneficios y/o perjuicios palpables. Aunque el retribucionismo logró un mayor grado de humanidad en la sanción o el escarnio del delincuente, no dejó de orientar la materialización de la justicia a este último, con el olvido de quien había sido afectado en forma directa con el crimen: la víctima (Beristain, 1998).

De manera paralela a lo planteado por Beristain (1998), se esgrimen teorías como la de la llamada 'ventana de la disciplina social', la cual define cuatro enfoques para la reglamentación de la conducta, a saber: punitivo, permisivo, negligente y restaurativo (McCold \& Wachtel, 2003). Según este modelo, la restaurativa es la mejor opción en lo que a la aplicación de la justicia se refiere, pues es el único enfoque que guarda un sano equilibrio entre el control estatal y el apoyo prestado a las partes en conflicto. Lo cual, significa que se toman medidas de contención frente al delito, se le considera una conducta reprochable e indeseada dentro del marco de la vida social y, por ello, se atiende una vez ocurre, pero sin que ello implique una calificación de desvalor respecto de la persona del ofensor, una etiqueta como delincuente o un desconocimiento de sus derechos; por el contrario, se le reconoce su papel central en la resolución del conflicto y se le invita a participar de un "compromiso cooperativo" (McCold \& Wachtel, 2003).

Diferentes autores (Umbreit y Coates, 2000; Strang, 2002; Zehr, 2007; Beck, Kropf, \& Leonard, 2011) coinciden en señalar que los orígenes de la justicia restaurativa son difusos; pese a ello, señalan como hito histórico, por una parte, la sentencia dictada por el juez Barry Stuart, en Ontario -Canadá-, en 1974, que exigió restaurar a las víctimas de los actos vandálicos cometidos por dos adolescentes. Por otra parte, Hudson (2012), indica que los programas de justicia restaurativa se originaron en 1972 en el Centro de Restitución de Minnesota (MRC), con la aparición de 
la resolución de conflictos como disciplina científica, aunque en su momento se le denominara de otra manera. A su turno, Bustos \& Larrauri (2000), Rojas (2009), Bernal \& Molina (2011) y Díaz (2013), le dan crédito al movimiento victimológico internacional surgido en la postguerra, afirmando que fueron las víctimas quienes advirtieron, en su afán por reivindicar su posición, la urgencia de cambiar las maneras de atender la criminalidad.

En todo caso, creer que lo restaurativo, como fin de la justicia, es una concepción moderna, es una idea bastante alejada de la realidad si se tiene en cuenta que se ha atribuido a culturas aborígenes, como las Maorí en Nueva Zelanda o los indígenas navajos de EE.UU., con sus Tribunales del Pacificador, prácticas comunitarias que entendían que la resolución de conflictos solo era posible cuando se convocaba a todos los involucrados y centraban su atención en la reparación del daño causado y no en el castigo del ofensor (Rojas, 2009; Hernández, 2011). Dentro de este recuento no pueden desconocerse las prácticas restaurativas de los indígenas colombianos, a quienes, por esta misma razón, se les reconoce una jurisdicción especial (Rojas, 2009).

La historia muestra que no se trata de un sistema nuevo de administración de justicia sino que guarda relación con el control social comunitario o que las mismas sociedades establecen como forma de autorregulación (Olson, 2001; Galain, 2010); eso sí, distinta a la idea de justicia que se tiene en los procedimientos judiciales de la justicia ordinaria, donde los presupuestos del conflicto dependen de referentes objetivos, derivados de principios jurídicos como el de legalidad, y la solución depende de un tercero (Atienza, 2001).

La justicia restaurativa, en palabras de Zehr (2007), es un movimiento o enfoque que surgió en un esfuerzo por atender las necesidades que el proceso penal tradicional no podía; por ello, Rojas (2009) la considera una filosofía o un paradigma sobre la justicia. Dentro de las dificultades que reportan los procesos penales tradicionales se encuentran: la de restaurar los malos tratos sufridos por las víctimas, a quienes, por no recibir una consideración y atención especiales, se les ocasionan nuevos traumas -victimización secundaria o revictimización (ONU, 2006)-; la 'desresponsabilización' del ofensor debido a la devaluación de la verdad durante el proceso; la violencia institucional que le impide al agresor generar empatía hacia la víctima y los efectos de la prisionalización que alejan al condenado de la resocialización, por nombrar algunos (Martínez \& Sánchez, 2011). La justicia restaurativa, entonces, incluye a otros que no son parte ni intervinientes en el proceso común $\mathrm{y}$, en este sentido, se erige como una filosofía conformada por un conjunto de principios y preguntas guía que proporcionan un esquema de pensamiento diferente para abordar el delito.

Para Sampedro (2003), la justicia restaurativa representa, además, una manera de determinar el éxito de la administración de justicia, pero no por el número de castigos impuestos a los delincuentes, sino por el grado de reparación del daño causado a las víctimas y a la comunidad. Así las cosas, la justicia restaurativa com- 
porta una visión de justicia que implica involucrar a las víctimas, los ofensores y la comunidad en la solución del conflicto y la restauración del daño causado; convoca a todos los que tengan un interés en una ofensa particular, para identificar y atender colectivamente los daños, necesidades y obligaciones derivados de aquella, con el propósito de sanar y enmendarlos de la mejor manera posible. En este mismo sentido la definen Márquez (2007), Domingo de la Fuente (2008), Rojas (2009), Bernal \& Molina (2010), Britto (2010), Etxebarria (2011), Castañer (2011), Díaz (2013) y Mazo (2013).

La Oficina de las Naciones Unidas contra la Droga y el Delito (2006), reconoce que muchos países, a raíz de la insatisfacción y la frustración frente a sus sistemas de justicia tradicionales, optaron por fortalecer las prácticas del derecho consuetudinario llamando a los directamente afectados y a la comunidad cercana a estos para que participaran de la resolución de los conflictos y la gestión de sus efectos. Afirma que "los programas de Justicia Restaurativa se basan en la creencia de que las partes de un conflicto deben estar activamente involucradas para resolver y mitigar sus consecuencias negativas" (p. 5).

Todos estos planteamientos suponen la inclusión de formas nuevas en el abordaje del fenómeno delictivo y respuestas diferentes a las que de forma tradicional se ofrecen con el proceso penal, enfocado en la persona del ofensor y la imposición de sanciones, antes que en reconocer, reparar y restaurar, a las víctimas del hecho criminal y en comprender que el delito afecta a la sociedad, a la cual el delincuente habrá de retornar en algún momento.

La definición de justicia restaurativa mencionada guarda correspondencia con lo planteado por la Corte Constitucional colombiana en la sentencia C-979 de 2005, en la cual reconoce que el sistema penal presenta disfuncionalidades basadas en la inequidad que hacen necesaria la introducción de métodos alternativos y la define así:

[1]a Justicia Restaurativa se presenta como un modelo alternativo de enfrentamiento de la criminalidad, que sustituye la idea tradicional de retribución o castigo, por una visión que rescata la importancia que tiene para la sociedad la reconstrucción de las relaciones entre víctima y victimario.

Las premisas que sustentan la existencia de la justicia restaurativa se basan en que el delito es un acto dañino que afecta a las personas y a las relaciones interpersonales, es decir, no parte de su entendimiento como una conducta típica, antijurídica y culpable. Para el modelo en comento, toda ofensa conlleva obligaciones para quien la causa y la principal de ellas es la de reparar el daño ocasionado. Por ello, su interés se vuelca en el daño a las personas y a las comunidades y en las necesidades asociadas a ello, e intenta que el ofensor comprenda las consecuencias de sus acciones y enmiende el daño, y que las comunidades también entiendan que tienen obligaciones, la primera de las cuales es prevenir la aparición del delito y reaccionar cuando el mismo se presenta. 
Así las cosas, los autores afirman que no puede hablarse de justicia restaurativa si no se cumplen las siguientes condiciones: (1) una aceptación de responsabilidad por parte del ofensor, como producto de la comprensión de lo lesivo de su conducta; (2) una ampliación del círculo de los interesados (víctima, ofensor, comunidad y Estado) en donde se promueve el compromiso y la participación, por cuanto cada involucrado juega un papel activo y decide sobre cómo se hace justicia; y (3) se logra una reparación directa o simbólica (Zehr, 2007; UNODC, 2006; Britto, 2010).

Para hacer esto posible, la víctima y el ofensor han de ser identificables y deben desear participar de manera voluntaria en esta forma de resolución del conflicto. Algunas de estas características fueron recogidas por el legislador colombiano en el art. 519 CPP, donde se indica que se requiere el consentimiento libre y voluntario de la víctima y el imputado, acusado o sentenciado de someter el conflicto a un proceso restaurativo, por lo cual quedan facultados para retirarlo en cualquier momento; advierte, además, que la participación del ofensor no se utiliza como prueba de la admisión de su culpabilidad en procesos ulteriores, o que el incumplimiento del acuerdo no puede emplearse como fundamento para la condena o la agravación de la pena (art. 519, numerales 1, 3 y 4). A lo anterior debe añadirse que los acuerdos alcanzados han de contener obligaciones razonables y proporcionadas al daño ocasionado (art. 519, numeral 2).

Cuando se afirma que la justicia restaurativa aparece, en el marco del derecho punitivo, para satisfacer una serie de necesidades desatendidas por el proceso penal, no significa que lo restaurativo niegue o desconozca la retribución (Zehr, 2007; Bernal \& Molina, 2010), pues, como se indicó, un pilar fundamental de lo restaurativo es que las ofensas comportan obligaciones y se busca que víctima y ofensor queden satisfechos con la manera como se resuelve el conflicto. Por ello, no puede afirmarse que la justicia restaurativa sea una manifestación del abolicionismo que pregona una supresión del concepto de delito (Bianchi, 1975; Mathiesen, Christie \& Hulsman, 1992), pues este último es, en realidad, un presupuesto para la actividad restaurativa.

De no aceptar la coexistencia entre la justicia restaurativa y los procesos coercitivos, sostiene Díaz (2010), la primera quedaría siempre relegada a una justicia marginal dentro de los sistemas de justicia criminal formales; eso no significa, sin embargo, que tal integración sea sencilla, pues es preciso hallar maneras de conjugarlas sin que se traicionen los principios y valores restaurativos.

Para Rojas (2009), la justicia restaurativa mira sobre todo al futuro, pero sin olvidar el pasado (acción). Estos principios, valga la pena aclarar, toman distancia de la resolución de conflictos en los términos planteados por autores como Winslade, (2013), Cobb (2013), Bush \& Folger (2006), Ury, Fisher \& Patton (1995), quienes tienen una concepción no jerárquica de los encuentros, por lo tanto no directiva, que no emite juicios de valor; $y$, en su lugar, ubica a las partes en igualdad de condiciones, sin rótulos o ideas preconcebidas, para que sean estas quienes definan en qué consiste el conflicto sin ser coaccionadas de ninguna manera. 
Otra precisión importante hace referencia a que la justicia restaurativa propende por una reparación integral o en sentido amplio, esto es, que más que una indemnización de los daños causados a la víctima -lo que se logra con el incidente de reparación o las acciones civiles derivadas del delito-, obliga a garantizar un cambio sustancial en las interacciones entre víctima, ofensor y sociedad, para lo cual el diálogo entre ellos es imprescindible y en donde caben otras formas de resarcimiento como el pedimento de disculpas o perdón, o la realización o abstención de ciertas conductas a favor de la víctima o la comunidad (Martínez \& Sánchez, 2011).

A todas luces, la puesta en práctica de estas estrategias sugiere flexibilidad en los procedimientos y, por ello, no puede hablarse de un 'debido proceso' en los términos de la justicia tradicional, pues los procedimientos están en constante reinvención y ajuste. La justicia restaurativa no parte, como el proceso judicial, de la presunción de inocencia, por el contrario, asume la aceptación de responsabilidad de los involucrados en el hecho que se espera superar. Existen, pues, falsas concepciones frente a los alcances que se le atribuyen al concepto examinado, por ejemplo, el de considerar que la justicia restaurativa solo se aplica en casos de delitos bagatela o en punto del Sistema de Responsabilidad Penal para Adolescentes, donde, de verdad, ha logrado importantes avances (Morris \& Maxwell, 1996; Rojas, 2009; Rodríguez, 2012). Creencias como las antedichas desconocen que la justicia restaurativa se afinca en el encuentro, la reparación, la reintegración y la inclusión como valores o notas esenciales (Zehr, 2007; Van \& Heetderks, 2015) y que, en definitiva, se trata de una justicia comunitaria que no puede equipararse a la de los jueces, a la tradicional del derecho.

\section{La mediación en la Ley 906 de 2004}

De acuerdo con la UNODC (2006), la mediación víctima-ofensor fue una de las primeras estrategias o programas de justicia restaurativa en ser aplicados en el mundo y se caracteriza porque se atiende las necesidades de las víctimas a partir del reconocimiento de la responsabilidad por parte de quien las ha perjudicado.

En el plano internacional, tiene cabida antes y después de la sentencia, o en los dos eventos dentro de un mismo caso. Cuando se lleva a cabo antes de la sentencia, por lo general es para que tenga efecto sobre esta; mientras que, cuando se efectúa en un escenario posterior, el efecto directo es sobre el proceso de rehabilitación y reinserción social. La recomendación principal versa sobre la posibilidad del encuentro cara a cara, con el propósito de que las partes en conflicto manifiesten sus sentimientos y redefinan la situación, gracias a la intervención de un mediador capacitado para ello, quien, casi siempre, genera una serie de encuentros individuales previos, de manera tal que se minimice el riesgo de revictimización. Esto no descarta la posibilidad de la llamada 'mediación indirecta', en la que el encuentro de la víctima y el ofensor nunca se lleva a cabo.

Para la UNODC (2006), la mediación exige como prerrequisitos básicos los siguientes: que el ofensor acepte o, por lo menos, no niegue su responsabilidad en el delito; que tanto la víctima como el ofensor deseen participar de esta forma de en- 
cuentro restaurativo y que ambas partes reflexionen acerca de cuán seguro es para ellos participar del proceso, lo cual presupone que estén bien informadas sobre el mismo y sus alcances. Una de sus ventajas es que las víctimas tienen la oportunidad de manifestar a su ofensor la manera en que el delito les afectó y obtener de él la información que consideren necesaria. El objetivo es que la mediación provoque reparación y compense, en cierta forma, las pérdidas que las víctimas han experimentado. En EE.UU., existen más de 300 programas de esta naturaleza y hay más de 500 en Europa; las investigaciones reflejan que, comparados con la vía judicial, estas estrategias generan una mayor satisfacción en las víctimas, mayor probabilidad de que los ofensores cumplan sus obligaciones de restitución y menor índice de delincuencia en las regiones donde se aplican (Domingo De la Fuente, 2008).

Si se parte de la base de que a la mediación penal le resultan aplicables todas las características de la justicia restaurativa ya vistas, por ser una estrategia derivada de ella, ella es, en palabras de Martínez \& Sánchez (2011), un movimiento social, una filosofía que recoge inquietudes muy diversas y que tiene que ver con la forma en que las sociedades reaccionan frente al delito. Estas autoras hacen referencia al “encuentro entre víctima y autor del delito, que tiene lugar con el fin de que ambas partes, a través del diálogo, lleguen a un acuerdo sobre cómo reparar el daño inferido y resolver el conflicto" (p. 58), conducidas por una persona imparcial llamada mediador. En similar sentido, el art. 523 CPP afirma que es

[u]n mecanismo por medio del cual un tercero neutral, particular o servidor público designado por el Fiscal General de la Nación o su delegado, trata de permitir el intercambio de opiniones entre víctima y el imputado o acusado para que confronten sus puntos de vista y, con su ayuda, logren solucionar el conflicto que les enfrenta.

Desde luego, es muy afortunada la redacción del artículo de no ser porque definió a la mediación como un 'mecanismo', con las dificultades que implica darle el mismo trato que han tenido los llamados 'Mecanismos Alternativos de Solución de Conflictos (M.A.S.C.)', implantados en la Ley 23 de 1991, derogada por la Ley 446 de 1998. La mediación no es uno de tales mecanismos; no debe serlo, no porque no resuelva conflictos, sino porque se corre el riesgo de considerarla como un medio práctico para la consecución de un fin. En otras palabras, la mediación no debe ser asumida como un M.A.S.C., justamente por el carácter alternativo a la justicia tradicional que de ellos se predica.

En el caso colombiano, los mecanismos 'alternativos' surgieron para descongestionar los despachos judiciales y no a causa de una verdadera apuesta por una política criminal transformadora o debido a una revolucionaria concepción de la justicia (Departamento Nacional de Planeación [DNP], 2015). Peña (2012), advierte como contraproducente asumir estas estrategias como mecanismos alternativos, pues ello significaría que son formas de "resolver conflictos de segunda categoría", dejando la sensación de que es una justicia "de segunda", "privada", "para pobres" o en "casos de poca monta" o para "conflictos menores", con lo cual refuerza la idea de que el proceso penal es el de verdad efectivo para los litigios importantes, 
públicos y en los que están en juego altas sumas de dinero. Para el mismo autor, otro problema de la alternatividad radica en que los recursos y esfuerzos se destinan a lo considerado principal o importante: el proceso judicial tradicional. Lo alternativo sigue a lo principal, de allí que, a las estrategias de resolución de conflictos como la conciliación, la mediación, el arbitraje o la amigable composición, se les hayan incorporado figuras y procedimientos propios del derecho, incoherentes con los fines perseguidos por la justicia restaurativa o la resolución de conflictos.

En ese orden de ideas, la mediación y la conciliación, desde la perspectiva de la justicia restaurativa y de la resolución de conflictos como disciplina, habrán de ser PRC (Programas de Resolución de Conflictos) o ERC (Estrategias de Resolución de Conflictos), pero no, Mecanismos Alternativos (M.A.S.C.). Los M.A.S.C. tienen infinitas bondades, pero la tradición jurídica colombiana los ha relegado y los ha convertido en simples instrumentos (mecanismos) al servicio de la justicia tradicional y, por lo tanto, los ha atado al derecho, con lo cual se olvida lo planteado en su momento en la Sentencia del 15 de diciembre de 1948: "es mejor procurar un entendimiento que litigar". Además, la mediación y la conciliación no pueden supeditar su aplicación solo en la medida en que favorecen aspectos procesales de la administración de justicia, (como el caso del requisito de procedibilidad que se predica de la conciliación en delitos querellables), sino que debe reconocerse en ellos su importancia, valor y poder en el tratamiento de conflictos.

Hechas estas precisiones, la esencia de la mediación radica, como lo sostienen Martínez y Sánchez (2011), en el "empoderamiento de las partes para que, a través del diálogo, puedan llegar a un acuerdo sobre la manera adecuada de reparar el daño causado con el delito". El reto consiste, entonces, en equilibrar las fuerzas entre la víctima y su ofensor, a través de la intervención del mediador, quien, a su vez, debe contribuir a que se delimite con suficiencia el conflicto objeto del debate, lo cual no equivale a afirmar que la mediación debe determinar los hechos objeto del proceso penal convencional, sino ofrecer una respuesta a ellos.

\section{El mediador en la Ley 906 de 2004 y su elección por parte de la Fiscalía General de la Nación.}

$\mathrm{Al}$ describir la mediación, el CPP afirma que el tercero neutral, llamado mediador, puede ser un particular o un servidor público, designado por el Fiscal General de la Nación o su delegado. El Manual de Procedimientos de Fiscalía (2006), indicó:

Conformación de listas de mediadores elegibles: El Jefe de Unidad de Fiscalías conformará la lista de mediadores, de acuerdo con las necesidades del servicio, la disponibilidad del recurso humano y la capacitación que tengan en medios alternativos de solución de conflictos; esta lista debe mantenerla actualizada. En los lugares donde existe más de una Unidad de Fiscalías, los jefes de unidad, conjuntamente, elaborarán la correspondiente lista (p. 216).

Según ese texto, estas listas debían elaborarse cada dos años y estar integradas por servidores públicos que, pese a ser funcionarios de la entidad, no podían 
ser fiscales. En cuanto a los particulares, la misión se encomendó a miembros de centros de conciliación, consultorios jurídicos, practicantes universitarios, colegios de abogados, organizaciones no gubernamentales (ONG) y otros capacitados en medios alternativos de solución de conflictos. La institución asumió la responsabilidad de examinar de manera constante la manera en que la labor se adelantaría y advirtió la iniciación de procesos disciplinarios a los mediadores que no cumplieran su labor como corresponde, de forma semejante al tratamiento dado en el país a la conciliación.

Una vez conformadas las listas, la Fiscalía estableció que de ellas se obtendría al mediador, quien, una vez notificado y con base en un reparto equitativo, habría de plantear los impedimentos o inhabilidades para acoger el encargo, cuyo estudio realizaría el fiscal de conocimiento. Según se dispuso, las partes podían rechazar la designación de manera fundada, caso en el cual se dispone una nueva designación; también, se acepta que sean los interesados quienes propongan al mediador. Hecha la designación, esta se notifica por cualquier medio idóneo, con inclusión de la fecha y hora programadas para la diligencia, y el mediador tiene cinco días para pronunciarse acerca de la aceptación del encargo, so pena de ser reemplazado e, incluso, excluido de la lista.

Aunque resulta comprensible que el legislador quisiera dejar en una entidad pública la reglamentación de esta figura y el encargo de definir quiénes habrían de ser los mediadores, la falta de apropiación de los principios restaurativos y de la resolución de conflictos llevaron a que, en la práctica, fueran funcionarios adscritos a los mismos despachos fiscales del proceso penal en curso, quienes terminaran fungiendo como mediadores en las estrategias restaurativas alcanzadas por esta vía. Así lo manifestaron algunos fiscales consultados para la realización de esta investigación (comunicación personal, 2 de noviembre de 2015), lo que desdibuja la intención de que este tercero facilitador sea una persona neutral al conflicto que las partes enfrentan.

Para garantizarlo, el papel de mediador debe recaer en personas ajenas al sistema y a cualquier interés en el ejercicio de la justicia tradicional, pues solo así se garantiza que lo debatido tome distancia del proceso penal y se cumplan sus fines.

\section{Asuntos que pueden tratarse en la mediación.}

En palabras del legislador, la mediación puede referirse a "la reparación, restitución o resarcimiento de los perjuicios causados; realización o abstención de determinada conducta; prestación de servicios a la comunidad; o pedimento de disculpas o perdón" (art. 523 CPP). Nótese que los asuntos objeto de mediación se refieren a compromisos u obligaciones que el ofensor adquiere con ocasión del hecho dañoso, lo que pone de manifiesto lo señalado internacionalmente, en torno al reconocimiento de la responsabilidad por parte del procesado como presupuesto para los programas restaurativos (Zehr, 2007). 
De otro lado, representa un acierto incluir cuestiones que nada tienen que ver con aspectos indemnizatorios o pecuniarios, aunque, por supuesto, estos también sean posibles y hayan quedado recogidos al hablar de reparación, resarcimiento o restitución de los perjuicios, pues, de otra manera, no se explica que una vez realizada, excluya la posibilidad de la acción civil derivada del delito y el incidente de reparación integral. La tendencia del derecho a concebir lo reparador desde lo pecuniario puede constituir una de las razones que desestimulen el empleo de la figura, toda vez que existen otras formas de consecución indemnizatoria que gozan de mayor aceptación y cuyo empleo resulta más familiar (Martínez \& Sánchez, 2011; Saray, 2013). Ejemplo de ello, son afirmaciones como la de Junco (2007):

Si no se llegó a un acuerdo [...] la actuación adelantada ante el mediador no tiene ninguna relevancia en el proceso mismo ni en la situación jurídica de las partes; simplemente se tratará de un intento informal de que un tercero mediara entre la víctima y el imputado o acusado. Pero si el acuerdo se lleva a cabo, constituye una especie de cosa juzgada entre las partes, pero solo en lo que implique aspectos patrimoniales (cursivas fuera del texto) (p. 517).

Otra cosa es afirmar, como lo indican Moya \& Reyes (s. f.), que los mecanismos de justicia restaurativa no constituyen "formas contractuales, pues, a diferencia de ellas, la dimisión no conlleva prestaciones a favor de la otra parte" (p. 317). Para estos autores, la mediación puede dar lugar a convenios extrapatrimoniales referidos al comportamiento, los servicios a la comunidad y el pedir disculpas o perdón, que no se consideran verdaderas obligaciones al estar desprovistas del contenido económico, cualidad que "condiciona la existencia misma de las prestaciones civiles" (p. 328). Así, aunque la mediación no verse sobre aspectos indemnizatorios (económicos), opera una presunción de derecho de que las mismas fueron absueltas, como lo plantean Moya \& Reyes (s. f.), pues nada más explica que limite la acción civil y el incidente de reparación integral.

\section{Momentos en los que procede celebrar mediaciones.}

La mediación penal tiene unas oportunidades de celebración específicas determinadas por la actuación procesal dentro de la cual se lleva a cabo. Conforme a lo establecido en el art. 524 de la Ley 906 de 2004, la misma procede

[d]esde la formulación de la imputación y hasta antes del inicio del juicio oral para los delitos perseguibles de oficio, cuyo mínimo de pena no exceda de cinco años de prisión, siempre y cuando el bien jurídico protegido no sobrepase la órbita personal del perjudicado, y víctima, imputado o acusado acepten expresa y voluntariamente someter su caso a una solución de Justicia Restaurativa. En los delitos con pena superior a cinco años la mediación será considerada para otorgar algunos beneficios durante el trámite de la actuación, o relacionados con la dosificación de la pena, o el purgamiento de la sanción.

La Ley 906 de 2004 establece los momentos procesales específicos en los que la mediación puede llevarse a cabo, lo cual indica que para el legislador esta figura solo tiene los efectos de los llamados 'programas alternativos', entendido por ta- 
les los que se llevan a cabo cuando el proceso penal ya ha iniciado y que pueden afectarlo en atención al resultado del encuentro entre la víctima y el victimario (Zehr, 2007). Se restringe así la posibilidad de utilizarla como un programa terapéutico o de sanación realizado sin que se afecte o se interfiera con el proceso judicial en curso y que puede llevarse a cabo, incluso con posterioridad a la condena. Tampoco podría aplicarse como programa de transición, el cual se caracteriza por desarrollarse mucho tiempo después de la condena, se enfoca en la reinserción y busca atender aquello que la condena no logra, con la consecutiva disminución del temor de la comunidad frente al delito y la persona del delincuente (Zehr, 2007). Este último evento se relaciona, por ejemplo, con el subrogado penal de la libertad condicional, cuya consecución se podría lograr con una estrategia restaurativa como la mediación.

Para Moya \& Reyes (s. f.), la razón de circunscribir la mediación a esta oportunidad procesal radica en que, a partir del juicio oral, no es posible variar la competencia del juez de conocimiento, lo que hace que una vez iniciado el juicio ya no sea procedente la celebración de acuerdos de ninguna índole.

Por su parte, los delitos perseguibles de oficio, cuyo mínimo de pena no excede los cinco años de prisión y que, además, no sobrepasan la órbita personal del perjudicado, es decir, aquellos en los cuales el bien jurídico afectado es disponible por las víctimas, por ser parte de su patrimonio autónomo y no tratarse de un interés de naturaleza estatal o sobre el que no se admiten acuerdos privados (Junco, 2007), son, en realidad, una proporción muy limitada. Así las cosas, si se analizan aquellos que sobrepasan la órbita personal del perjudicado, en términos generales y sin desconocer que siempre habría que hacerse un análisis del caso concreto, se excluyen los delitos contra la fe pública, el orden económico social, los recursos naturales y el medio ambiente, la seguridad pública, la salud pública, los que atentan contra los mecanismos de participación democrática, la administración de justicia, la eficaz y recta impartición de justicia, la existencia y seguridad del Estado y el régimen constitucional y legal; con lo cual queda reducido el espectro a los delitos contra la vida y la integridad personal, algunos delitos contra el DIH, la libertad individual, los delitos sexuales, la integridad moral, la familia, el patrimonio económico, la protección de información y de datos y los derechos de autor. Si de este último grupo se extraen los delitos querellables, es preciso descartar los delitos contra la integridad moral, salvo las imputaciones de litigantes, siete delitos contra la vida y la integridad personal, de los casi treinta y cinco que conforman el título; la violación a la libertad religiosa, dos delitos contra la familia, de los diez posibles y dieciséis delitos contra el patrimonio económico, de los treinta que aproximadamente constituyen este grupo.

Grosso modo, de los trescientos cincuenta delitos que componen la ley penal, la mediación resulta procedente en cerca de cien conductas punibles que, no siendo querellables, tampoco sobrepasan la órbita personal del perjudicado. Si a esto se suma que la pena mínima no ha de superar los cinco (5) años de prisión, la lista se reduce de forma considerable. Por ello, señala Velásquez (2010): “[e]n relación con 
la mediación la situación es diferente pues la figura no opera y todo se queda en meras declaraciones de buena voluntad del legislador que, por esta vía, se torna en un mero rey de burlas" (p. 35).

Esta disposición impide que la justicia restaurativa se consolide como una verdadera apuesta de política criminal, susceptible de ser aplicada en toda suerte de casos e ignora que la mediación es una estrategia, precisamente, de justicia restaurativa con capacidad para generar efectos jurídicos y no una estrategia jurídica capaz de generar efectos de resolución de conflictos, como usualmente ha pasado con los M.A.S.C. y con otras figuras que se erigen como alternativas a lo punitivo (DNP, 2015). Lo señalado por el legislador pone de manifiesto el temor del derecho a sacar de su jurisdicción aquellos conflictos que revisten mayor gravedad o que se consideran más lesivos, pues, aunque la mediación proceda frente a delitos investigables de oficio, las restricciones siguen circunscribiéndola a conductas consideradas no tan graves.

La aplicación de los mecanismos de justicia restaurativa de la Ley 906 de 2004 quedó supeditada al proceso judicial, reforzando una vez más la idea de que su importancia depende de él, pues las partes podrán recurrir a uno u a otro en atención al estadio procesal en que se encuentren: la conciliación preprocesal antes de que inicie, la mediación en el lapso comprendido entre la formulación de imputación y antes del inicio del juicio oral o cuando ha fracasado la conciliación preprocesal, conforme al inciso $3^{\circ}$ del art. 522 (Moya \& Reyes, s. f.; Fiscalía General de la Nación, 2006a; Junco, 2007) y, de nuevo, la conciliación, pero dentro del incidente de reparación integral cuando haya una condena en firme.

\section{Diferencias entre la conciliación y la mediación.}

Es aquí donde resulta relevante distinguir entre la mediación y la conciliación, pues la postura de quien escribe es que la incorporación de estas dos estrategias de justicia restaurativa en la Ley 906 de 2004 no dependió de un análisis concienzudo en torno a las notas que las caracterizan, sino de la necesidad de contar con 'mecanismos' al servicio del ejercicio judicial, a tono con la preocupación por el desgaste de la administración de justicia, antes que el deterioro del tejido y de los lazos sociales que producen los conflictos.

Para empezar, es preciso anotar que la distinción entre estos conceptos genera gran controversia, pero en Colombia el asunto es aún más complejo si se tiene en cuenta que, en el plano normativo, se erigen como figuras independientes y no como sinónimos, según lo que ocurre en otras latitudes (DNP, 2015). Lo que el ordenamiento jurídico denomina 'conciliación', el resto del mundo lo llama 'mediación'; en muchos países, la primera de las expresiones ni siquiera se menciona o se conoce como 'mediación evaluativa', en contraposición a la 'mediación facilitativa', que se asemeja más a la manera en que se concibe a la mediación en Colombia (Della Noce, 2010). 
Así, uno de los pocos países en los cuales la mediación se diferencia de la conciliación es Colombia, porque la conciliación tiene el estatus de mecanismo alternativo de resolución de conflictos desde su creación. La mediación, por su parte, no había tenido un desarrollo legal hasta la aparición de la Ley 906 de 2004, pese a que en el plano internacional siempre ha existido como programa de justicia restaurativa, dentro de los que también se encuentran los círculos de sentencia o tratados de paz, los paneles de víctimas o paneles de impacto y las conferencias familiares (UNODC, 2006, Tapias, 2015; Díaz, 2013).

Así las cosas, si Colombia llama conciliación a la mediación, ¿a qué se hace referencia cuando se habla de mediación, como para indicar que es una figura independiente de aquella? Una de las primeras distinciones entre la mediación y la conciliación la plantea la Sentencia de Casación de la Corte Suprema de Justicia del 15 de diciembre de 1948, la cual cita a Carnelutti, para quien

(1)a mediación (...) persigue una composición contractual cualquiera, con intervención de un mediador que aproxima a los litigantes pero que no tiende a procurar una solución de justicia, y la conciliación que también requiere la intervención de un tercero, conciliador, que sí aspira a una composición justa.

La idea de que la conciliación podía materializar la justicia en mejor modo, resultó ser, quizás, el argumento más sólido para que fuese esta estrategia de resolución de conflictos la más apetecida por el ordenamiento jurídico colombiano. Por ello, se convirtió en una figura estrictamente reglada y adquirió el estatus de 'mecanismo de mecanismos' en Colombia, tanto es así que, a la fecha, cuenta con una ley propia (Ley 640 de 2001) e innumerables textos que se ocupan de ella (Márquez, 2012). Asimismo, es el único 'mecanismo' susceptible de impactar en las estadísticas (Velásquez, 2010), aun cuando su aplicación sea incipiente, comparada con las cifras de judicialización de los conflictos, y el efecto sobre la descongestión de los despachos judiciales o su posibilidad de facilitar el acceso a la justicia sean insuficientes, tras 25 años de su aparición (Departamento Nacional de Planeación, 2015). Por el contrario, a la mediación se le consideró una figura propicia para otro tipo de asuntos 'no jurídicos' o no interesados en la materialización de justicia, al menos no de la manera en que la coincide la ciencia jurídica tradicional.

Para Shane (1995), el NADRAC (1999) y autores como Friedman \& Himmelstein (2009) y Della Noce (2010), la diferencia se le atribuye al grado de injerencia que tiene el tercero facilitador para participar en la resolución del conflicto, lo cual depende de su preparación y experticia. Así, se afirma que el conciliador goza de mayores facultades que el mediador para proponer fórmulas de arreglo e intervenir en el conflicto de las partes y sus propuestas suelen estar amparadas en criterios formales, como la ley. Hay quienes sostienen, incluso, que al mediador le está vetado proponer fórmulas de arreglo (Departamento Nacional de Planeación, 2015). Otra diferencia reconocida por los autores radica en los efectos jurídicos que tiene la no consecución del acuerdo: mientras que, para la conciliación, el fracaso del encuentro agota un requisito para el acceso a la justicia tradicional (condición 
de procedibilidad), en la mediación, tal situación no tiene efecto jurídico alguno (Osorio, 2002; Junco, 2007) y es como si el encuentro jamás se hubiese llevado a cabo.

En Colombia, esta discusión no ha sido pacífica ni parece tener mucho consenso, pero, por lo que se observa en la práctica, al conciliador se le atribuyen muchas más facultades decisorias que al mediador, pese a considerarse que ambas figuras son de autocomposición intermedia (o de heterocomposición intermedia, como las denomina Junco, 2007), es decir, en las que las partes en conflicto son quienes lo resuelven, con la ayuda o intervención de un tercero facilitador que no tiene la calidad de autoridad (Junco, 2007). Es por ello que la mediación solo tuvo reconocimiento formal en la ley (aunque incompleto y desacertado) hasta la aparición de la Ley 906 de 2004, pues, con anterioridad a ello, los dos conceptos se utilizaban de manera indistinta o como sinónimos (Corte Constitucional, 2001, Sentencia C-1195).

Así las cosas, las diferencias son de forma y no de fondo, pues, si se leen los fines que ambas figuras persiguen y se observa un encuentro, sin conocer la figura que en el caso particular se aplique, el observador no podría reconocer si se trata de una conciliación o de una mediación, lo cual pone de manifiesto que comparten su esencia y que las distinciones de forma se las imprimieron las normas (Neuman, 2005).

Con base en lo expuesto, puede precisarse que, en materia penal, la conciliación y la mediación presentan las siguientes diferencias: la conciliación, es un requisito de procedibilidad tratándose de los delitos querellables, mientras que la mediación es un acto de mera liberalidad de una o de las dos partes que, por desfortuna, se ha restringido a los delitos perseguidos de oficio, cuya pena mínima no exceda de 5 años. En lo atinente a las calidades del facilitador, se tiene que el conciliador debe ser abogado titulado, salvo las excepciones del art. $5^{\circ}$ de la Ley 640 de 2001 (estudiantes de consultorio jurídico, personeros municipales y notarios no titulados), mientras que el mediador no precisa de ningún título profesional específico, permitiendo la actuación de profesionales de múltiples disciplinas, siempre que tengan el entrenamiento y la formación adecuados. Frente a las sesiones o encuentros en que se desarrolla la figura, la conciliación, por regla general, ocurre en uno solo, el señalado en fecha y hora para la audiencia de conciliación; la mediación, a su turno, puede cumplirse en varios encuentros, incluso con sesiones independientes entre víctima y victimario, mientras se consiguen las condiciones propicias para un encuentro cara a cara (Junco, 2007).

\section{Una última diferencia es la que señala Velásquez (2010) cuando indica que}

[m]ientras en la conciliación la solución al conflicto es producto de un juzgamiento, adelantado por quien está autorizado para ejercer una potestad jurisdiccional y hacer ejecutar sus decisiones; en la mediación, ello es consecuencia de un acuerdo razonable entre los involucrados, a instancias de un tercero (que puede ser un particular o un servidor público) investido de una potestad jurisdiccional privada que no le permite hacer ejecutar lo acordado. 
En conclusión, puede afirmarse que, aparte de estos distingos de forma que les imprimió la Ley 906 de 2004, no hay nada en la manera de llevarlas a cabo que permita hacer una diferencia importante entre ellas, como tampoco las debe haber en la formación y el perfil de los facilitadores que interceden entre las partes.

\section{Solicitud para llevar a cabo una mediación penal.}

El art. 525 CPP propone una reflexión adicional, pues sostiene que la mediación podrá solicitarse por parte de la víctima o por el imputado o acusado ante el fiscal, el juez de control de garantías o el juez de conocimiento, según sea el caso, para que el Fiscal General de la Nación o su delegado para esos efectos, proceda a designar al mediador.

No se entiende la razón por la cual el juez de control de garantías fue incluido en este listado, si se tiene en cuenta que la ley procesal penal limita sus intervenciones a las audiencias preliminares que, por cierto, se realizan con unos fines específicos; a menos que sean audiencias preliminares innominadas, como las que posibilita el numeral 9 del art. 154 CPP (Ospina, 2013). Aún en el evento de considerar que en la formulación de la imputación o en otra audiencia preliminar, víctima o victimario hicieran su manifestación de voluntad de someter el conflicto a un acuerdo restaurativo como la mediación, el juez de control de garantías no podría hacer nada distinto a poner en conocimiento de la fiscalía la situación.

Para Moya \& Reyes (s. f.), la labor del juez de control de garantías será la de verificar que la decisión de someter el conflicto a esta vía es libre y consensual. Si lo que se pretendía con ello era facilitar a los interesados comunicar sus intenciones, se cae en lo contrario, pues dilata el trámite y le añade pasos innecesarios. Incluso, debe verse con precaución, en atención a la filosofía restaurativa según la cual una vez lograda la mediación esta se presenta al juez de control de garantías para un control de legalidad, pues la preocupación por la legalidad es propia de los principios aplicados a los procedimientos judiciales y la mediación, desde la justicia restaurativa, no es tal. La legalidad solo podría predicarse de los efectos procesales penales que tiene el acuerdo logrado en la mediación, no de su contenido, pues eso solo importa a los involucrados. Sobre esta premisa se hace especial énfasis: la mediación no es, ni debe ser, un procedimiento judicial. En igual sentido lo afirman Moya y Reyes (s. f.) al indicar:

Si bien el artículo 526 de la Ley 906 de 2004 indica que el juez valorará el informe del mediador, es de observar que dicha valoración no puede ser instancia, sino de verificación de los efectos, dependiendo de la situación que se trate y, desde luego, del resultado (pp. 327-328).

Más desafortunada aún es la inclusión del juez de conocimiento en la lista, pues poseer esta información podría contaminarlo, en especial, si se tiene en cuenta que la justicia restaurativa parte de que quien genera una ofensa debe reconocerla y repararla. Si la mediación penal para la Ley 906 de 2004 es un mecanismo de justicia restaurativa, a la mediación se le aplican los mismos principios de aquella 
y esto resulta lógico, pues quien tiene certeza de su inocencia en un caso penal, o considera que su actuar en nada ha perjudicado a quien se anuncia como víctima o a terceros, difícilmente estará interesado en recurrir a la justicia restaurativa, al menos en los términos señalados por la ley.

Quizás al percibir esta situación, en las reglas generales se advierte que la participación del imputado, acusado o sentenciado no se utiliza como prueba de admisión de culpabilidad (art. 519 numeral 3), aspecto que guarda absoluta correspondencia con el literal $d$ del art. $8^{\circ} \mathrm{CPP}$, en el cual se afirma que, en ejercicio del derecho a la defensa, el contenido de las conversaciones tendentes a lograr un acuerdo para la declaración de responsabilidad en cualquiera de sus formas, no podrá ser utilizado en contra del procesado, si no llegare a perfeccionarse.

Así las cosas, desde el punto de vista jurídico las prohibiciones y exigencias que el juzgador tiene son claras, pero no puede ignorase la importancia que, desde la perspectiva psicológica, tiene el poseer cierta información que puede ser privilegiada al momento de construir juicios de valor y hacer raciocinios frente a la responsabilidad del sujeto. Si el juez de conocimiento sabe de la intención de mediar, en especial, si la iniciativa parte del procesado, aun cuando no conozca o presencie los encuentros entre la víctima y el ofensor, difícilmente obviará el contemplar la responsabilidad de este último en la comisión del delito o, al menos, lo tendrá como un hecho bastante probable, susceptible de afectar la presunción de inocencia.

La solicitud de mediación debería, pues, elevarse ante el fiscal o, bien, ante el defensor, para que estos recurran al Fiscal General o a su delegado y adelanten los trámites correspondientes, sin participación alguna del juez. Moya \& Reyes (s. f.) indican que, a diferencia de los preacuerdos, los acuerdos basados en justicia restaurativa no se condicionan a la aceptación expresa o implícita de responsabilidad por parte del procesado, lo que en efecto se corresponde con lo establecido en la ley, sin embargo, esto va en contravía con los postulados de la justicia restaurativa para la cual, como se vio, el reconocimiento de la responsabilidad es un presupuesto esencial.

\section{Efectos procesales de la mediación.}

La mediación, según el art. 526 CPP, tiene efectos vinculantes, por lo tanto, excluye el ejercicio de la acción civil derivada del delito y el incidente de reparación integral. Esta prohibición resulta entendible, toda vez que, al ocuparse la mediación de aspectos como la reparación, la restitución o el resarcimiento de los perjuicios causados, tanto la acción civil como el incidente se tornan innecesarios, en especial este último, sobre todo si se tiene en cuenta que, además de la restitución de perjuicios, la mediación puede llevar a las partes a comprometerse a realizar o abstenerse de ciertas conductas, prestar servicios comunitarios, ofrecer disculpas o pedir perdón, lo que hace que, en efecto, se predique integralidad en la reparación del daño, al tratarse aspectos que van más allá de lo netamente pecuniario o económico. 
Los resultados de la mediación contenidos en el informe elaborado por el mediador, habrán de remitirse al fiscal o al juez, dice la norma, quienes, luego de valorarlo, determinarán sus efectos en la actuación. Estos efectos pueden darse en dos sentidos: para extinguir la acción penal o para ser tenidos en cuenta al momento de imponer la pena, en este último caso, afectando la manera en que se aplica la coerción personal o la individualización.

Es de aclarar que la mediación por sí misma no extingue la acción penal, no es una de las causales de extinción contenidas en el art. 77 CPP, pero sirve como vehículo para lograr ese propósito, a través de otras instituciones jurídicas (Velásquez, 2010). Ospina (2016), plantea cuáles son tales vías al referirse a las salidas alternas al proceso, al indicar que la mediación favorece, entre otras cuestiones, la aplicación del principio de oportunidad, en especial cuando este se da en su modalidad de suspensión. Los resultados de la mediación, entonces, no son suficientes para que la extinción de la acción penal opere de manera automática, pero pueden ser el insumo para la solicitud de la suspensión del procedimiento a prueba, incluso, para que la fiscalía renuncie al ejercicio de la acción penal. Así lo refiere el numeral 7 del art. 324 CPP, referente a las causales para la aplicación del principio de oportunidad:

El principio de oportunidad se aplicará en los siguientes casos:

7. Cuando proceda la suspensión del procedimiento a prueba en el marco de la Justicia Restaurativa y como consecuencia de este se cumpla con las condiciones impuestas.

Puede ocurrir, así mismo, que un acuerdo de mediación implique tal forma de reparación integral de la víctima que se cumplan los presupuestos del numeral primero del art. 324 CPP. Pero no es solo el principio de oportunidad el que se beneficia con la realización exitosa de una mediación, sostiene Ospina (2016); con ella puede invocarse otras salidas alternas como el desistimiento, la indemnización integral, la retractación, el pago (en los casos de emisión ilegal de cheque) o el resarcimiento del daño (cuando este recae sobre bien ajeno), salidas todas que extinguen la acción penal cuando se recurre a la solicitud y el posterior decreto de la preclusión del art. 332 CPP, específicamente en el numeral uno: la imposibilidad de iniciar o continuar el ejercicio de la acción penal.

Nótese, sin embargo, que la mayoría de estas figuras procede frente a delitos querellables que son, justo es decirlo, los que resultan excluidos de la norma, al afirmarse que la mediación es susceptible de aplicarse en delitos perseguibles de oficio, cuyo mínimo de pena no exceda de 5 años. El desistimiento, por ejemplo, se predica de las querellas (artículo 76 del CPP, modificado por el artículo 6 de la Ley 1826 de 2017); en el caso de la indemnización integral, figura propia de la Ley 600 de 2000, (artículo 42), los únicos delitos que admitirían una mediación serían el homicidio culposo cuando no concurra alguna de las circunstancias de agravación 
punitiva, los de lesiones personales dolosas con secuelas transitorias, los delitos contra los derechos de autor y en algunos procesos por los delitos contra el patrimonio económico.

Tratándose de la retractación en los delitos contra la integridad moral (artículo 225 y siguientes del CP), es preciso recordar que ellos están contenidos dentro del artículo 74 del CPP que los define como querellables, misma situación que experimentan el cheque ilegal y el daño en bien ajeno. Bajo ese panorama, la lista de delitos susceptibles de ser ventilados en un escenario de mediación, es reducida con lo cual una vez más se demuestra el limitado alcance que se le ha dado a la figura; esto, desatiende no solo lo restaurativo que la inspira sino los principios rectores y garantías procesales de la Ley 906 de 2004, como la prevalencia del derecho sustancial (artículo 10), los derechos de las víctimas (artículo 11) y la integración (artículo 25). Desde luego, ante la imposibilidad de materializar la justicia restaurativa en estos delitos a través de la figura de la mediación, quedaría la oportunidad de recurrir a la conciliación extraprocesal regulada por la Ley 640 de 2001 (Ospina, 2016).

El otro gran efecto de la mediación, desde el punto de vista procesal penal, aparte de la extinción de la acción a través de las vías ya vistas, es el que tiene el acuerdo logrado entre las partes respecto a la imposición de la pena, por cuanto puede afectar la manera en que se aplica la coerción personal o la individualización, según lo dicta la norma. En cuanto a la coerción personal, puede pensarse que la mediación apoye los criterios para lograr el subrogado de la suspensión condicional de la ejecución de la pena, lo cual impide que en un lapso de entre 2 y 5 años el condenado sea privado de su libertad (art. 63 del Código Penal), pues para ello se requiere que la pena impuesta no supere los tres años de prisión -lo cual está dentro del margen previsto para la mediación-; además, que los antecedentes personales, sociales y familiares y la modalidad y gravedad de la conducta, la hagan innecesaria y que la multa impuesta se haya pagado en forma total (este último requisito, adicionado por la Ley 890 de 2004).

En lo que respecta a la coerción personal, la mediación también puede jugar a favor de la concesión de una prisión domiciliaria (art. 38 del Código Penal, modificado por el artículo 22 Ley 1709 de 20 de enero de 2014), pues también aquí se exige que la conducta punible tenga una pena mínima de 5 años de prisión o menos. Los demás requisitos de la prisión domiciliaria -el buen desempeño del sentenciado en los planos personal, familiar, laboral o social y el cumplimiento de ciertas obligaciones enumeradas en la norma- caben dentro del concepto de "reparación, restitución o resarcimiento de perjuicios, realización o abstención de conductas y prestación de servicios comunitarios", de que habla el art. 523 CPP.

Respecto de la individualización de la pena de que trata el art. 447 CPP, es preciso recordar que, si el fallo resulta ser condenatorio o si se acepta el acuerdo logrado entre la fiscalía y la defensa, el juez concede la palabra a las partes para que se refieran a las condiciones individuales, familiares, sociales, modo de vivir y ante- 
cedentes del culpable. Si lo consideran conveniente, podrán referirse a la probable determinación de pena aplicable y la concesión de algún subrogado. En el evento de que la mediación haya permitido reparar voluntariamente el daño, al menos de manera parcial, o haya indemnizado a los perjudicados, se podrá invocar la causal contenida en el numeral 6 del art. 55 del Código Penal, relativo a las circunstancias de menor punibilidad (Junco, 2007; Ospina, 2013).

En este mismo sentido, el inciso final del art. $524 \mathrm{CPP}$, a tono con el cual "[e]n los delitos con pena superior a cinco (5) años la mediación será considerada para otorgar algunos beneficios durante el trámite de la actuación, o relacionados con la dosificación de la pena, o el purgamiento de la sanción", que excluye la extinción de la acción penal, pero que permite, bajo el presupuesto de la configuración de causales de menor punibilidad, la aplicación del sistema de cuartos se haga de manera más benevolente para el procesado e, incluso, que se confiera la libertad condicional.

\section{El papel de la comunidad en la mediación penal.}

Si bien se ha mencionado que la participación de la comunidad es inherente a los procesos restaurativos, ello no significa que la participación comunitaria se dé por igual en todos los modelos o programas. Tal intervención se percibe mucho más acentuada en estrategias como los círculos de sentencia o las conferencias familiares, pero no en la mediación penal, internacionalmente conocida como mediación víctima-ofensor (Tapias 2015; Díaz, 2013).

\section{Aportes para el Manual sobre Mediación Penal}

Lo más cercano al cumplimiento de la obligación impuesta por el legislador a la Fiscalía General de la Nación, en el sentido de elaborar un manual que fijara las directrices de funcionamiento de la mediación, en particular en la capacitación y evaluación de los mediadores y las reglas de conducta que regirían el funcionamiento de la figura (art. 527 CPP), es el Capítulo XII del Manual de Procedimientos de Fiscalía del año 2006. Frente a la instrucción de dictar las reglas de funcionamiento de los programas de justicia restaurativa, se elaboró un manual que lleva el mismo nombre, divulgado entre los funcionarios de la entidad el 30 de septiembre de 2004, pero que no incluyó nada distinto a lo ya señalado en la ley, en los arts. 518 a 521 (Fiscalía General de la Nación, 2004b).

\section{Directrices de funcionamiento de la mediación dadas por la Fiscalía General de la Nación.}

Conforme a lo establecido en el Manual de Procedimiento de Fiscalía (2006), una vez recibida la solicitud de mediación se debe verificar que esta cumpla con los siguientes requisitos: (1) que se identifiquen el caso y la autoridad que está conociendo del mismo; (2) la individualización de las partes involucradas, con inclusión de sus representantes legales cuando se trate de incapaces; (3) una manifestación expresa de someter su conflicto a esa forma de solución; (4) datos de contacto 
de las partes, sus apoderados y representantes legales. El original se dirige al fiscal encargado del reparto y cada una de las partes recibe una copia del documento.

El Manual establece que, de ser improcedente, se le informa al solicitante, lo que sugiere un primer juicio o apreciación de la intención de mediar. De ser aceptada, se indaga a la otra parte su intención de participar en el programa y, si esta se niega, se informa al solicitante y se deja la respectiva constancia. De dársele curso, las partes deben estar notificadas sobre el encuentro por lo menos diez días antes de llevarse a cabo. Iniciada la mediación, las partes pueden retirarse de ella en cualquier momento.

El trámite requiere que cada una de las partes entregue un breve escrito en el que exponga su posición frente a los asuntos que esperan se resuelvan. El mediador se encarga de que dichos documentos sean conocidos por el oponente, intercambiándolos.

En una primera sesión, agrega el Manual, "las partes deberán aportar toda la información que sea necesaria para que el mediador pueda desempeñar adecuadamente su función". Dicho mediador podrá pedir a las partes que complementen la información suministrada y "realizará tantas sesiones como sean necesarias para la solución de la controversia, siempre que advierta un avance en la solución de la misma" (p. 219). Pese a que se reconoció que las sesiones serían privadas, se habilitó a las partes para acompañarse de un asesor, quien no habría de intervenir, pero que podría ser consultado por la parte a quien acompaña. La naturaleza o calidades del asesor no quedaron establecidas, pero esta figura resulta muy similar a la competencia dada en la Ley 640 de 2001 a los apoderados de las partes que los asisten en la audiencia de conciliación, lo que pone de manifiesto la similitud entre la mediación penal de la Ley 906 de 2004 y la conciliación extraprocesal.

En lo que respecta al mediador, se le impuso el veto de divulgar información relacionada con el caso, respetando o atendiendo la confidencialidad que cobija a este tipo de procedimientos, o fungir como testigo en juicio $\mathrm{u}$ otros procedimientos judiciales. Aunque el manual no lo menciona, debería entenderse que la restricción opera respecto de procesos judiciales de los casos en los que ha servido como mediador y no frente a otro tipo de diligencias o actividades relacionadas con la administración de justicia. La confidencialidad también es un imperativo para las partes, obligadas a no emplear "expresiones, reconocimientos, informaciones, documentos o propuestas conocidas en la mediación, para argumentar o presentar pruebas en la actuación a la cual se vincula la mediación ni en ningún otro procedimiento judicial o de otra índole" (p. 220).

Frente a la estrategia de resolución de conflictos, el Manual guarda silencio, lo que supone discrecionalidad del mediador para conducir los encuentros, bajo cualquiera de las teorías existentes para tal fin. Por ello, a renglón seguido, describe las causales de culminación del proceso, sin hacer mayores precisiones en torno a su ejecución. Dentro de las causales de terminación se encuentran el acuerdo que 
pone fin a la controversia y la pérdida de posibilidad, utilidad o justificación de los encuentros.

Para terminar, señala que "las reglas de la mediación deberán ser interpretadas de conformidad con los fines de la Justicia Restaurativa y aplicadas conforme con la Constitución Política y la Ley", y que las erogaciones en que deba incurrirse "serán asumidos de forma equitativa por las partes, salvo acuerdo en contrario", pero "si el gasto se origina en petición o prueba de parte, su beneficiario lo cubrirá" (p. 220).

Como viene de verse, el Manual no definió un procedimiento como tal, sino que se limitó a describir algunos aspectos del encuentro inicial, faltando al imperativo de describir las reglas de conducta para poner en marcha la figura (art. 527 CPP).

\section{Propuesta de capacitación y evaluación de los mediadores que intervienen en procedimientos de mediación penal.}

La reglamentación hecha por la Fiscalía desatendió la instrucción de fijar directrices en torno a la capacitación y la evaluación de los mediadores y las reglas de conducta que regirían el funcionamiento de la figura. Esta falencia cobra relevancia en la media en que la ausencia de unos perfiles claramente definidos y de los criterios para la operación de estrategias de resolución de conflictos y de justicia restaurativa han llevado a que en el país estas iniciativas no hayan tenido resultados tan positivos como los esperados (Peña, 2012; Departamento Nacional de Planeación, 2015).

Así mismo, en lo que respecta a los mediadores es claro que quien funge como facilitador o interventor en la justicia restaurativa ha de ser un sujeto con la preparación suficiente para comprender las dimensiones del conflicto derivado del delito y para coordinar encuentros que, en efecto, reivindiquen los derechos de las víctimas sin desconocer los que le asisten al procesado y a los entornos inmediatos de cada uno (Redorta, 2004). El éxito de la mediación depende, en cierto sentido, del mediador, personaje que tiene un perfil deseable, que cuenta con una formación específica y a quien acompañan unos determinados rasgos de personalidad (López \& García-López, 2010; Salvador \& García, 2010; Díaz, 2013), pues, como lo menciona Bernal (2011), el facilitador es el primero en convencerse en que esta vía resuelve el conflicto y es eficaz frente a los fines que persigue. Esas calidades o cualidades específicas, según el Departamento Nacional de Planeación (2015), son las competencias del ser, el saber y el saber hacer.

\section{Interdisciplinariedad y mediación penal.}

En lo que coinciden los diferentes autores (Fernández \& Ortiz, 2008; Bernal, 2011; Díaz, 2013; Peña, 2015), es en que la mediación debe tener un carácter interdisciplinar, toda vez que los conflictos generados con el delito tienen diversas aristas, cuyo análisis y abordaje requiere de varias miradas y el aporte de cada una de ellas en la construcción de un acuerdo que satisfaga a las víctimas, a los ofensores 
y a la comunidad. La interdisciplinariedad, en este sentido, se entiende como la integración de

[i]nformación, datos, técnicas, herramientas, perspectivas, conceptos y / o teorías de dos o más disciplinas o cuerpos especializados de conocimiento, orientados a avanzar una comprensión fundamental o resolver problemas cuyas soluciones yacen más allá del ámbito de una sola disciplina o área de práctica investigativa (Academia Nacional de Ciencias, 2005, p. 2, citada por Uribe, 2011).

La interdisciplinariedad es un concepto genérico que incluye la multidisciplinariedad, la interdisciplinariedad propiamente dicha y la transdisciplinariedad (Uribe, 2011). Las disciplinas tradicionales se caracterizan por tener un objeto de estudio, un método y unas teorías que, en relación con los conflictos que genera el delito, pueden dividirse en dos grandes grupos: (a) las ciencias sociales, dentro de las que se encuentran la historia, la sociología y la antropología; y (b) las ciencias humanas, que agrupan a la psicología y la filosofía (Dilthey, 1951), por lo cual el derecho es una disciplina que navega entre uno y otro grupo. Cuando los fenómenos se abordan de modo multidisciplinar, cada disciplina se pronuncia respecto a la manera como, desde su campo de conocimiento, se percibe un determinado fenómeno; por ello, en lo multidisciplinar no hay diálogos o encuentros entre las disciplinas, solamente una concurrencia de perspectivas, de allí que la multidisciplinariedad sea una pregunta por el objeto de estudio. Por su parte, cuando se habla de interdisciplinariedad, las disciplinas que confluyen en el análisis del fenómeno se entrecruzan y encuentran bajo el interés de resolver dilemas de manera conjunta; es una cuestión de método, en donde se pueden identificar convergencias e intersecciones. En el caso de la transdisciplinariedad, la convergencia de disciplinas genera un producto que bien puede ser un nuevo método, una nueva teoría o un nuevo problema de estudio, en cualquier caso, un nuevo conocimiento, una innovación (Morin, s. f.).

Estas precisiones se hacen para poner de presente que la intervención del conflicto y la consecución de la justicia restaurativa no deben estar supeditadas a la actuación del derecho y de los abogados de manera exclusiva, como tampoco a la psicología, la antropología, la sociología, la pedagogía o a la comunicación social, sino a todas ellas en conjunto, pues el objeto de estudio, esto es, el conflicto derivado del delito, posee una esencia que no le corresponde o puede escriturársele a ningún saber particular. Así las cosas, la formación o capacitación del mediador, antes que basarse en fórmulas jurídicas o efectos del acuerdo, debe versar sobre aspectos que le permitan intervenir el conflicto no en calidad de terapeuta o consejero, como lo señala Del Val (2015), sino como lo que en realidad es: el actor que intercede entre las partes para lograr la reparación de la víctima, a partir de la toma de conciencia de la responsabilidad que frente a ello le asiste al ofensor, poniéndolas de acuerdo frente a las diferencias y distancias que ha creado el delito, en donde la formación profesional de base no puede ser un criterio incluyente o excluyente para el cumplimiento de la labor. La apuesta, entonces, apunta a procurar que el 
trabajo del mediador implique hacer lecturas de diferente orden, y se reconozca la multicausalidad de los conflictos derivados de un delito.

\section{El perfil del mediador.}

Antes de exponer los temas en los cuales deberían recibir capacitación los mediadores, es preciso indicar que los aspirantes al cargo han de contar con unas competencias o cualidades mínimas (del ser), relacionadas con sus recursos personales y características de personalidad, lo que puede constituirse como un 'perfil de ingreso' al ciclo de formación. Por tales habilidades se entienden la capacidad de autocrítica y su propia actitud frente a los conflictos, una actitud de vida conciliadora y pacífica, sensibilidad frente a los dilemas humanos y las problemáticas sociales, conducta altruista e interés por las poblaciones vulnerables, pensamiento abierto y flexible.

Desde el modelo de las cinco grandes dimensiones de la personalidad, estas características son susceptibles de ser evaluadas e identificadas, determinando su grado de presencia o ausencia en la estructura psicológica de un individuo; así, se considerarían deseables como mediadores los sujetos que se muestran proclives a la extraversión, la atención de sus sentimientos interiores, la curiosidad, la apertura hacia las nuevas ideas y los valores no convencionales, y la tendencia a experimentar emociones positivas; así mismo, las personas altruistas que simpatizan fácilmente con los demás y que están dispuestas a ayudarles. Los mediadores deberían ser personas capaces de controlarse y resistirse a los impulsos (Costa \& McCrae, 2002).

La formación del mediador, una vez elegido este perfil de ingreso, debe estar enfocada en las temáticas específicas de justicia restaurativa, teoría del conflicto y su resolución, teorías de la comunicación y habilidades emocionales, acompañadas de un fuerte componente práctico que permita el entrenamiento suficiente para llevar estos conocimientos a su aplicación en los casos concretos.

\section{Capacitación en teoría del conflicto y la resolución de conflictos.}

En lo que respecta a la teoría del conflicto y su resolución, es preciso recordar que existen tres modelos teóricos tradicionalmente empleados, a saber: el tradicional lineal de la escuela de negociación de Harvard; el transformativo; y el circular narrativo (Demicheli, 2000; Peña, 2015).

El primero de ellos, concibe al conflicto como el efecto de una causa antecedente (lineal) y se caracteriza por centrar su objetivo en la consecución de acuerdos, por lo cual logra que las partes en conflicto tengan uno a otro la percepción de haber ganado con él, lo que las deja satisfechas (negociación cooperadora o gana-gana). Se sustenta en tres postulados básicos: separar a las personas del conflicto; las fórmulas de arreglo siempre deben considerar el mutuo beneficio; y las partes deben centrarse en los intereses comunes antes que asumir posiciones obstinadas (Ury, Fisher \& Patton, 1995). 
Para el modelo transformativo, el conflicto es una oportunidad de cambio y crecimiento, siempre que las partes asuman una actitud constructiva ante él (Bush \& Folger, 2006). Su objetivo apunta a transformar la relación existente entre las partes.

Para terminar, el modelo circular define al conflicto como

[u]n todo inevitable, producto de la diversidad, más que la expresión de intereses o necesidades personales. La definición del conflicto será entonces el marco conceptual que le permitirá al mediador intervenir en los conflictos de las partes. De esta manera, si el conflicto es la diferencia entre las narrativas, la gestión del conflicto debe ser a través de las narrativas mismas (Peña, 2015, p. 3).

Con base en esta concepción del conflicto, el mismo se supera en la medida en que las narrativas negativas se reemplazan por narrativas alternativas que permiten reconocer al otro, colaborarle y respetarle. Al entender el conflicto como narrativa, el mediador está llamado a facilitar los canales de comunicación entre víctima y ofensor, en aras de que modifiquen sus pautas de interacción.

Dados los objetivos perseguidos por la justicia restaurativa en general, y la mediación en particular, en criterio de quien escribe, el modelo transformativo y el circular narrativo parecen los más adecuados para el entrenamiento de los mediadores, toda vez que, en el caso del modelo transformativo, su objetivo es

[e]l mejoramiento de las propias partes, en comparación con lo que eran antes; en este tipo de mediación se alcanza el éxito cuando las partes como personas cambian para mejorar a través del crecimiento en las dos dimensiones del desarrollo moral: Capacidad de fortalecer el yo y la capacidad de relacionarse con otros (Peña, 2015. p. 2).

Y, en el caso del modelo circular narrativo, su objetivo se centra en permitir a las partes que se separaren de la historia conflictiva en la que se encuentran para construir una nueva historia, donde el respeto, la colaboración y el reconocimiento mutuo sean sus cimientos (Winslade, 2013), dando especial importancia a la oralidad y al diálogo en el que se construyen las percepciones y los imaginarios. Para Peña (2015), la teoría narrativa afirma que

[1]os conflictos son historias, el hombre es lo que dice y esto refleja su forma de entender la vida a través de las palabras que utiliza. Las personas viven sus conflictos a través de narrativas gracias a las cuales las partes se perciben como contrarias.

La intervención de un mediador en los programas de justicia restaurativa no puede desconocer la importante tradición científica que existe en torno a las experiencias exitosas sobre aquella en el mundo y los avances de la resolución de conflictos como disciplina científica. Pretender que sus intervenciones se hagan de manera empírica, en especial en conflictos tan delicados como los derivados de la comisión de delitos, es irresponsable de parte del Estado y sus instituciones, no solo por los costos procesales que ello implica sino por los intereses en juego. 
De allí la necesidad de que los modelos sobre teoría del conflicto y sus formas de resolución se conozcan y apliquen de manera consciente.

\section{Capacitación en teorías de la comunicación.}

Otro foco de capacitación ha de centrarse en las teorías de la comunicación y su relación con el conflicto, máxime cuando se considera que, con ocasión del delito, las partes construyen narrativas negativas que se deben cambiar. La mediación, en cualquiera de sus formas, es esencialmente un proceso de comunicación (Demicheli, 2000).

En cuanto al modelo facilitativo de la escuela de Harvard, el mediador es un regulador de la comunicación entre las partes, directivo al momento de propiciar los encuentros, bajo la premisa de que la relación entre las partes ha impedido un diálogo efectivo que debe ser organizado para que los respectivos planteamientos lleguen a ser conocidos por el oponente (Ury, Fisher \& Patton, 1995). El papel que el modelo facilitativo otorga al mediador, sugiere la puesta en escena de la teoría matemática de la comunicación de Shannon \& Weaver (1949), según la cual las personas se comunican estableciendo turnos de interacción, lo que la hace lineal (emisor-mensaje-receptor). Bajo su propuesta, la comunicación consiste en la transmisión de información en lo que se conoce como un mensaje entre el emisor y el receptor, suministrada a través de un canal y bajo un contexto específico que los afecta (Shannon \& Weaver, 1949). Ante la presencia del conflicto, esta linealidad se interrumpe, generándose ruidos o distorsiones que bloquean, alteran o dificultan la comunicación. Los ruidos son factores externos a la comunicación que afectan negativamente la integralidad de los mensajes. El papel del mediador consistirá, entonces, en asumir un rol neutral, pero superior, que dirige un proceso surtido en tres etapas: el análisis, la planeación y la discusión, con el objetivo de conseguir una solución colaborativa, no distributiva, disminuyendo las diferencias (Berlo, 1984; Demicheli, 2000; Aguado, 2010; Méndez, 2004).

En lo que respecta al modelo transformativo, son las teorías de Watzlawick, Beavin \& Jackson (1985) sobre el pragmatismo de la comunicación humana, las que explican los problemas de comunicación en los conflictos. Para estos autores, la comunicación se compone de interacciones que, a diferencia del modelo matemático, no son secuenciales sino simultáneas y circulares desde su génesis y en toda su duración. Plantearon cinco axiomas o principios de la comunicación humana: (1) es imposible no comunicar; (2) toda comunicación tiene un nivel de contenido y uno de relación; (3) la naturaleza de una relación depende de la forma de puntuar las secuencias de comunicación que cada participante establece, es decir, de la interpretación; (4) las personas utilizan la comunicación digital y la analógica en sus interacciones; $y$, (5) todo intercambio comunicacional es simétrico o complementario. Bajo esta teoría, el papel del mediador deberá consistir, en lo que a problemas comunicativos respecta, en identificar las incongruencias entre el lenguaje verbal y no verbal, dialogar sobre la manera como cada parte percibe el problema que les enfrenta, tomar conciencia sobre sus interacciones, evidenciar los 
sentimientos y emociones que les acompañan y, por supuesto, emplear las técnicas que caracterizan al modelo y las teorías subyacentes a él (Demicheli, 2000).

La teoría de la comunicación en la que se ampara el modelo narrativo es la CMM (Coordinated Management of Meaning), propuesta por Pearce (s. f.), como contraposición a la teoría de los tipos lógicos de Russell (1905) en la que se habían basado Watzlawick, Beavin \& Jackson (1985) para proponer sus planteamientos sobre la pragmática de la comunicación humana. Para Pearce (s. f.), no todos los intercambios comunicativos de los seres humanos que trasgreden la lógica generan paradojas en la comunicación que la hacen inviable. En su criterio, existen jerarquías en los niveles de significación que, a través de la reflexividad, hacen posible los cambios de significación.

Es innegable la importancia que el estudio de la comunicación tiene en la resolución de conflictos, lo que sustenta la importancia de la capacitación que, en este sentido, han de recibir los mediadores. No obstante, la prioridad que suele otorgarse a la necesaria capacitación de naturaleza jurídica, resta oportunidades a los facilitadores de recibir instrucción sobre aspectos neurálgicos de cara a los asuntos a atender (DNP, 2015).

\section{Formación en habilidades para identificar emociones.}

De esta manera, lo que se busca desarrollar es la capacidad de un individuo para darse cuenta, aceptar, comprender y ajustar sus propias emociones y las de quienes le rodean. Las investigaciones sobre el papel de las emociones en el comportamiento humano fueron mencionadas por autores como Thorndike (1935) y Wechsler (1940), entre otros (Salovey \& Mayer, 1997; Eysenck, 2000; Martínez \& Sánchez, 2011; Bisquerra, 2012).

Quienes se forman como facilitadores para la resolución de conflictos deben poder gobernar sus propias emociones, lo que aumenta las posibilidades para interpretar y relacionarse de manera efectiva con los demás y ser más eficaces en sus contactos interpersonales. Así mismo, son sujetos proclives a desarrollar empatía (ponerse en el lugar de los otros) y crear relaciones sociales (Ortiz, 2004), habilidades esperadas en un mediador. En la investigación científica sobresale, también, la llamada teoría de la mente, concepto que, según Tirapu, Pérez, Erekatxo \& Pelegrín (2007) \& Martínez (2011), se encuentra en los trabajos de Premack \& Woodruff (1978), y hace referencia a la capacidad para entender y predecir comportamientos de otros, así como lo que conocen, sus intenciones, emociones y creencias. Para sus autores originales:

[a]l decir, que un sujeto tiene una Teoría de la Mente, queremos decir que el sujeto atribuye estados mentales a sí mismo y a los demás [...] Un sistema de inferencias de este tipo se considera, en un sentido estricto, una teoría; en primer lugar, porque tales estados no son directamente observables, y en segundo lugar, porque el sistema puede utilizarse para hacer predicciones, de forma específica, acerca del comportamiento de otros organismos (Premack \& Woodruff, 1978, pp. 515-526). 
La capacitación de los mediadores debe desarrollar su capacidad de atribuir estados mentales a otros, siendo un aspecto esencial en ello la empatía (Gómez, Molina \& Arana, 2013). Así, un programa de formación en mediación, aparte de los tópicos ya vistos (teoría del conflicto y modelos de resolución, teorías de la comunicación y su relación con el conflicto), debe incluir lo que atañe en forma directa a las habilidades propias de los mediadores, a partir de sus recursos personales y los procedimientos que, sin ser una camisa de fuerza, den las directrices, siempre desde modelos científicos comprobados (Barona, 2011).

\section{Conclusiones}

La justicia restaurativa representa un paradigma o visión de la justicia, que se aleja de considerar lo justo como la imposición de castigos o sanciones para la persona del delincuente y que, en contraposición, se centra en la reparación y/o restitución de los daños causados a las víctimas. Propende por el encuentro entre las partes en conflicto, de manera tal que se atiendan las necesidades de los afectados y las responsabilidades de los ofensores, en pro de la reintegración de unos y otros a la sociedad y la reconstrucción del tejido social. En este sentido, tiene por objetivos: restaurar el orden y la paz en las comunidades, así como reparar las relaciones humanas que han sufrido daño; reafirmar la intolerancia hacia el delito y los valores sociales; apoyar a las víctimas y satisfacer sus necesidades; lograr que los ofensores se hagan responsables de sus actos, previniendo conductas delictivas futuras y favoreciendo su reincorporación a la sociedad.

Son diversas las estrategias que se pueden implementar para lograr justicia restaurativa; desde la perspectiva internacional se incluyen: los círculos de sentencia o tratados de paz, los paneles de víctimas o paneles de impacto, las conferencias familiares y la mediación víctima-ofensor. Esta última, caracterizada por propiciar encuentros entre quien sufre las consecuencias del delito y quien realiza la acción delictiva, para que, a través de la manifestación de sus puntos de vista y sus sentimientos, se logre redefinir la situación y se concreten formas de reparación, sin que terceros distintos al facilitador (mediador) intervengan.

En el caso colombiano, la ley de procedimiento penal incluyó un título denominado 'justicia restaurativa', que consagró como mecanismos de la misma a la conciliación y a la mediación, lo que podría llevar a pensar que el legislador se mostró interesado en que se atendieran los problemas que, entre las partes, genera la comisión de un delito y que el proceso penal tradicional no logra resolver; sin embargo, al analizar la manera como se reglamentaron estos mecanismos, en especial lo concerniente a la mediación, esa intención queda en entredicho y, en su lugar, parece que la incorporación de la justicia restaurativa obedeció a móviles de naturaleza política (Velásquez, 2010) o de economía procesal, antes que una preocupación por la reparación del daño causado a las víctimas y la reconstrucción del tejido social. 
En lo que respecta a la manera como la mediación penal fue definida por el legislador, se encuentran elementos a favor y en contra, cuando se les compara con los postulados universales de la justicia restaurativa, así:

Primero, la definición coincide con el tratamiento y concepción que en el plano internacional se tiene de la figura, excepto por el hecho de definirla como mecanismo, lo que sugiere que su utilidad está determinada por la manera en que impacte o beneficie a la administración de justicia o los intereses particulares de no llevar a juicio ciertos procesos.

Segundo, con respecto a los mediadores, la ley se limita a indicar que pueden fungir como tales los particulares o los servidores públicos y a establecer el procedimiento para su elección, pero no desde la perspectiva de un perfil esperado o sus competencias y habilidades.

Tercero, en lo atinente a los asuntos tratables en una mediación se incluyen todos aquellos que concuerdan con los objetivos de la justicia restaurativa, pero, al momento de definir los efectos de los acuerdos, se percibe una tendencia a concebir la mediación desde la perspectiva puramente pecuniaria o económica. Con respecto a su procedencia, son tantas las limitantes que el espectro de acción de la figura queda bastante reducido.

Cuarto, dentro del ordenamiento procesal penal colombiano, la mediación y la conciliación son figuras independientes, pero las diferencias son de forma antes que de fondo. Esto resulta esperado si se tiene en cuenta que en el resto de países se consideran sinónimos y no coexisten en los ordenamientos, entre otras cuestiones, porque no hay diferencias fundamentales entre ellas.

Quinto, una de las principales dificultades frente a la presentación de la solicitud de mediación consiste en que el legislador permitió que esta se elevara ante el juez de conocimiento, favoreciendo la contaminación que esta información pueda generar en el juzgador, en el evento de que el acuerdo no se consiga.

Por otra parte, aunque la ley encargó a la fiscalía de indicar los aspectos relacionados con la capacitación de los mediadores y su evaluación, esta tarea no se realizó. En criterio de quien escribe, es preciso escindir a la mediación y a los programas de justicia restaurativa de los escenarios judiciales para que tengan éxito. En ese orden de ideas, los mediadores no deben ser funcionarios de la fiscalía ni de ninguna otra entidad que pueda tener interés hacia alguna de las partes en conflicto, sino que la labor debe recaer en cabeza de personas especializadas en resolución de controversias que tengan independencia de las instituciones de administración de justicia y que puedan dedicar a la puesta en escena de estas estrategias el tiempo y la dedicación que la labor demanda. Esta capacitación debe versar sobre aspectos como la teoría del conflicto y su resolución, las teorías de la comunicación y su relación con el manejo de disputas, así como de habilidades de empatía y reconocimiento de emociones, en otros, acompañado de horas suficientes de entrenamiento práctico. La elección de las personas aptas para recibir forma- 
ción de mediadores debe estar determinada por un perfil claramente establecido y unas cualidades personales deseables, específicas.

La enorme responsabilidad que acompaña a quienes intervienen como facilitadores en la resolución de un conflicto, especialmente en el ámbito de lo penal, por la cantidad de intereses en juego, obliga a que el desempeño de los mediadores sea estrictamente evaluado y certificado. De esta manera se puede controlar que solo perfiles cualificados asuman el encargo y se materialicen los objetivos de la justicia restaurativa. Esta garantía redunda, por lo demás, en beneficios para la administración de justicia y los propósitos que, en materia procesal penal, se espera que la figura cumpla.

La capacitación de los mediadores exige la construcción de un currículo consistente y muy bien estructurado que le permita a la mediación salir de verdad a la luz y posicionarse como un auténtico programa de justicia restaurativa, en cuya virtud cada uno de los núcleos de formación sean coherentes y articulados a una visión del conflicto y su resolución, de cara a evitar mezclas que, sin un norte específico, conjugan teorías y modelos, en ocasiones del todo opuestos entre sí.

La existencia de una política criminal que haga una apuesta por la justicia restaurativa no puede dejar en manos de funcionarios sin formación el manejo de conflictos tan delicados como los derivados de la comisión de delitos; de allí la importancia de que la reglamentación de la mediación penal tenga un espacio en la agenda del sistema y sus necesarias reformas, a las cuales se ha pretendido aportar con este estudio.

De no producirse una reforma sustancial sobre la manera en que la figura debe operar, esta tendrá, en lo sucesivo, la misma suerte que corrieron los llamados mecanismos alternativos de solución de conflictos, en definitiva ineficaces para cumplir con el propósito que acompañó su creación.

El éxito de la mediación como programa de justicia restaurativa en Colombia está determinado por la menor probabilidad que tenga el proceso penal en curso de interferir en los acuerdos logrados por las partes y en la motivación de sus participantes. Ello no significa que los logros restaurativos de la mediación no puedan tener eventuales efectos dentro de dichos procesos, pero los mismos no pueden restringir su ejercicio y puesta en marcha. La mediación penal debe ser una posibilidad en los escenarios de post condena, como parte de la política criminal del Estado, y no solo como una acción paralela que puede o no desarrollarse en el curso de un proceso activo. Esta separación incluye una apuesta real por la interdisciplinariedad que se exige en un adecuado manejo de los conflictos. No se trata, entonces, de abolir el proceso penal, sino de crear un procedimiento que lo complemente.

El reto para el futuro, entonces, es consolidar un sistema de justicia restaurativa en materia penal encargado de poner en marcha las estrategias que le resultan propias (mediación y conciliación), que no esté en manos de las entidades públicas 
ya constituidas, y que se encargue de la selección, formación y evaluación de los mediadores, en donde las partes puedan recurrir a resolver sus conflictos con la tranquilidad que da la independencia del proceso judicial en curso. De esta manera se disminuyen los riesgos de la privatización y se evita que la intención de las partes, al menos de los procesados, no sean las ganancias jurídicas, sino el interés por reparar a sus víctimas y construir una mejor sociedad.

\section{Referencias}

Aguado, M. (2010). El papel de la mediación entre la familia y la escuela como prevención de la violencia. Revista de Mediación 3(6), 22-31.

Atienza, M. (2001). El sentido del derecho. Bogotá: Ariel.

Barona, S. (2011). Mediación Penal: fundamento, fines y régimen jurídico. Valencia: Tirant Lo Blanch.

Beck, E., Kropf, N., \& Leonard, P. (2011). Social work and restorative justice: Skills for dialogue, peacemaking, and reconciliation. Oxford: Oxford University Press.

Beristain, A. (1998). Criminología y Victimología. Alternativas re-creadoras al delito. Bogotá: Leyer.

Berlo, D. (1984). El proceso de la comunicación: Introducción a la teoría y a la práctica. Buenos Aires: El Ateneo.

Bernal, F., \& Molina, M. (2010). Proceso Penal y Justicia Restaurativa: La necesaria búsqueda de soluciones fuera del sistema acusatorio. Bogotá: Nueva Jurídica.

Bernal, T. (2011). El camino de la mediación: un modelo de trabajo desde la práctica. En E. García-López (Comp.), Mediación. Perspectivas desde la Psicología Jurídica (pp. 41-93). México: Manual Moderno.

Bianchi, E. (1975). Hacia un derecho penal privado. Concilium (107), 88-112.

Bisquerra, R. (2012). ¿Cómo educar las emociones? España: FAROS.

Britto, D. (2010). Justicia Restaurativa: Reflexiones sobre la experiencia en Colombia. Ecuador: Universidad de Loja.

Bush, R., \& Folger, J. (2006). La promesa de mediación. Argentina: Gránica.

Bustos, J., \& Larrauri, E. (2000). Victimología: Presente y futuro. Bogotá: Temis.

Castañer, V. (2011). Justicia y Prácticas Restaurativas: Los Círculos Restaurativos y su aplicación en diversos ámbitos. España: Fundación Universitaria Iberoamericana.

Cobb, S. (2013). Hablando de violencia. EE.UU.: Oxford University Press. 
Costa, P. \& McCrae, R. (2002). Inventario de Personalidad NEO Revisado. Madrid: TEA Ediciones.

Del Val, T. (2015). Mediación en materia penal. Argentina: Cathedra Jurídica.

Della Noce, D. (2010). Evaluative mediation: In search of practice competencies. Conflict Resolution Quarterly, 27(2), 193-214. doi: 10.1002/crq.255

Demicheli, G. (2000). Comunicación y modelos de mediación: epistemología, teoría y técnicas. Revista Estudios Sociales, 106(4), 1-13.

Departamento Nacional de Planeación (2015). Análisis conceptual del Sistema Nacional de Conciliación en Colombia en sus 25 años: Construyendo diálogo y paz para el futuro. Bogotá: DNP.

Díaz, A. (2010). La Experiencia de la Mediación Penal en Chile. Política Criminal, 5(9), 1-67. Recuperado de http://www.politicacriminal.cl/Vol_05/n_09/ Vol5N9A1.pdf

Díaz, F. (2013). Conflicto, mediación y conciliación desde una mirada restaurativa y psicojurídica. Bogotá: Ibáñez-PUJ.

Dilthey, W. (1951). Psicología y teoría del conocimiento. Bogotá: Fondo de Cultura Económica.

Domingo de la Fuente, V. (2008). Justicia Restaurativa y mediación penal. Lex Nova. 23, 1-41.

Etxebarria, X. (2011). Justicia Restaurativa y fines del Derecho Penal. En M. Martínez y M. P. Sánchez (Eds.), Justicia Restaurativa, mediación penal y penitenciaria: un renovado impulso, (pp. 47-68). Madrid: Reus S. A.

Eysenck, M. (2000). Cognition and emotion. En M. Eysenck \& M. Keane. Cognitive Psychology, (pp.489-512). EEUU: Mc Graw Hill.

Fernández, J., \& Ortiz, M. (2008). Los conflictos: cómo desarrollar habilidades como mediador. Madrid: Pirámide.

Fiscalía General de la Nación (2006a). Manual de Procedimientos de Fiscalía en el Sistema Penal Acusatorio Colombiano. Bogotá: FGN.

Fiscalía General de la Nación (2006b). Manual de Justicia Restaurativa. Bogotá: FGN.

Friedman, G., \& Himmelstein, J. (2009). Challenging Conflict: Mediation Through Understanding. EEUU: Harvard Law School.

Galain, P. (2010). La reparación del daño a la víctima del delito. Valencia: Tirant Lo Blanch.

García-López, E. (2011). Mediación. Perspectivas desde la psicología jurídica. Bogotá: Manual Moderno. 
Gómez, M.; Molina, D., \& Arana, M. (2013). Teoría de la mente en un grupo de personas vinculadas al conflicto armado y en proceso de resocialización. Revista Colombiana de Ciencias Sociales, 4(2), 244-257.

Hernández, G. (2011). La conciliación judicial como mecanismo para el logro de la Justicia Restaurativa. En E. García-López (Comp.). Mediación. Perspectivas desde la psicología jurídica. (pp. 159-186). México: Manual Moderno.

Hudson, J. (2012). Contemporary Origins of Restorative Justice Programming: The Minnesota Restitution Center. Federal Probation, 76(2), 49-55.

Junco, J. (2007). La conciliación: Aspectos sustanciales y procesales y en el sistema acusatorio. Quinta edición. Bogotá: Temis-Jurídica Radar.

Ley 23 de 1991. Por medio de la cual se crean mecanismos para descongestionar los Despachos Judiciales, y se dictan otras disposiciones. Diario Oficial No. 39.752. Congreso de la República de Colombia, marzo de 1991.

Ley 446 de 1998. Por la cual se adoptan como legislación permanente algunas normas del Decreto 2651 de 1991, se modifican algunas del Código de Procedimiento Civil, se derogan otras de la Ley 23 de 1991 y del Decreto 2279 de 1989, se modifican y expiden normas del Código Contencioso Administrativo y se dictan otras disposiciones sobre descongestión, eficiencia y acceso a la justicia. Diario Oficial No. 43.335. Congreso de la República de Colombia, julio de 1998.

Ley 600 de 2000. Por la cual se expide el Código de Procedimiento Penal. Diario Oficial No. 44.097. Congreso de la República de Colombia, julio de 2000.

Ley 640 de 2001. Por la cual se modifican normas relativas a la conciliación y se dictan otras disposiciones. Diario Oficial No. 44.303. Congreso de la República de Colombia, enero de 2001.

Ley 890 de 2004. Por la cual se modifica y adiciona el Código Penal. Diario Oficial No. 45.602. Congreso de la República de Colombia, julio 2004.

Ley 906 de 2004. Por la cual se expide el Código de Procedimiento Penal. Diario Oficial No. 45.658. Congreso de la República de Colombia, septiembre de 2004. Bogotá: Ibáñez.

López, M., \& García-López, E. (2010). El perfil del mediador. En E. García-López (Ed.), Fundamentos de Psicología Jurídica y Forense (pp. 373-396). México: Oxford University Press.

Márquez, A. (2007). La Justicia Restaurativa versus la justicia retributiva en el contexto del sistema procesal de tendencia acusatoria. Prolegómenos-Derechos y Valores 10(20), 201-212. 
Márquez, A. (2012). La conciliación penal como mecanismo de Justicia Restaurativa. Bogotá: Universidad Militar Nueva Granada.

Martínez, M., \& Sánchez, M. (2011). Justicia Restaurativa, mediación penal y penitenciaria: un renovado impulso. Madrid: Reus S. A.

Martínez, M. (2011). Intersubjetividad y teoría de la mente. Psicología del Desarrollo 1(2), 9-28.

Mathiesen, T.; Christie, N. \& Hulsman, L. (1992). Abolicionismo penal (trad. M. Ciafardini \& M. Bondanza). Buenos Aires: Ediar.

Mazo, M. (2013). La mediación como herramienta de la Justicia Restaurativa. Opinión Jurídica. 12(23), 99-114.

McCold, P., \& Wachtel, T. (2003). En busca de un paradigma: una teoría sobre la Justicia Restaurativa. E Forum Restorative practices, 10(15), 1-3.

Méndez, A. (2004). Perspectivas sobre comunicación y sociedad. Valencia: Quiles.

Morandé, P. (2000). Familia y sociedad. Chile: Universidad de Chile.

Morin, E. (s. f.). Sobre la interdiscplinariedad. Recuperado de: file: / / C: / Users / Andrea\%20L/Downloads/morin_sobre_la_interdisciplinaridad\%20(2)\%20(2). pdf

Morris, A., \& Maxwell, G. (1996). Juvenile Justice in New Zeland: A new paradigm. En Australian and New Zeland Journal of Criminology (16), 72-90.

Moya, M., \& Reyes, C. (s. f.). Salidas alternas y derecho de defensa. En J. Arias (Ed.), Plan Nacional de Capacitación: sistema nacional de defensoría pública. (pp. 171-332). Bogotá: Defensoría del Pueblo-USAID.

NADRAC-Attorney General's Department (1999). A fair say. Managing Differences in Mediation and Conciliation. Australia: NADRAC-AGD.

Neuman, E. (2005). La Mediación Penal y la Justicia Restaurativa. México: Porrúa.

Oficina de las Naciones Unidas contra la Droga y el Delito. (2006). Manual sobre Programas de Justicia Restaurativa. Viena: ONU.

Olson, C. (2001). Aplicando la Mediación y los Procesos de Consenso en el marco de la Justicia Restaurativa. En E. Carranza (Coord.), Justicia Penal y sobrepoblación penitenciaria: Respuestas posibles (pp. 214-236). México: Siglo XXI.

Ospina, V. (2013). Modalidad de suspensión del criterio de oportunidad. En M. Moya (Ed.), La Defensa (pp. 209-250). Bogotá: Defensoría del Pueblo.

Ospina, V. (2016). Análisis de la salida alterna "aceptación de cargos": Cuestionamientos y propuestas desde la defensa pública. Bogotá: Defensoría del Pueblo. 
Pearce, B. (s. f.). A brief introduction "the coordinated management of meaning (CMM). Recuperado de CMM Institute: http:/ / www.cmminstitute.net/sites/default/ files / documents / A-brief-introduction-of-CMM-2002.pdf

Peña, H. (2012). 20 años del Sistema Nacional de Conciliación. Bogotá: Ministerio de Justicia y del Derecho.

Peña, H. (2015). Mediación narrativa: técnicas y método para resolver conflictos en las organizaciones. DIXI 17(22), 1-22.

Premack, D., \& Wodruff, G. (1978). Behavioral and Brain Sciences. Cambridge Journals, 1(4), 515- 526. doi: http:/ / dx.doi.org/10.1017/S0140525X00076512

Redorta, J. (2004). Mediación: Cómo analizar los conflictos. Barcelona: Paidós.

Rodríguez, L. (2012). Análisis de la Justicia Restaurativa en Materia de Responsabilidad Penal para Adolescentes en Colombia. Anuario de Psicología Jurídica, 22, 25-35.

Rojas, C. (2009). Justicia Restaurativa en el Código de Procedimiento Penal Colombiano. Bogotá: Doctrina y Ley.

Russell, B. (1905). On denoting. Oxford Journals, (56), 479-493.

Salovey, P., \& Mayer, J. (1997). Emotional intelligence. Imagination, cognition and personality, 9, 185- 211.

Salvador, C., \& García-López, E. (2010). Compromiso e inteligencia emocional en mediadores del poder judicial de Oaxaca. México: Diversitas Perspectivas en Psicología. 6(2), 375-387.

Sampedro, J. (2003). La humanización del proceso penal. Bogotá: Legis.

Saray, N. (2013). Incidente de reparación integral de perjuicios en la Ley 906 de 2004. Bogotá: FGN-Department of Justice.

Sentencia C-1195 (2001, noviembre 15). M.P. Manuel José Cepeda Espinosa y M.P. Marco Gerardo Monroy Cabra. Corte Constitucional. Recuperado de http:/ / www.corteconstitucional.gov.co/ relatoria/2001/c-1195-01.htm.

Sentencia C-979 (2005, septiembre 26). M.P. Jaime Córdoba Triviño. Corte Constitucional. Recuperado de http://www.corteconstitucional.gov.co/ RELATORIA/2005/C-979-05.htm.

Shane, M. (1995). Differences between Mediation \& Conciliation. Dispute Resolution Journal, 50(3), 31-33.

Shannon, C., \& Weaven, W. (1949). A Mathematical Theory of Communication. The Bell System Technical Journal, (27), 379-656. 
Strang, H. (2002). Reparo o venganza: víctimas y Justicia Restaurativa. Oxford: Clarendon.

Tapias, A. (2015). Victimología en América Latina. Bogotá: Librería de la U.

Tirapu, J.; Pérez, G.; Erekatxo, M., \& Pelegrín, C. (2007). ¿Qué es la teoría de la mente? Revista de Neurología. 44(8), 479-489.

Thorndike, E. (1935). The Psychology of Wants, Interests, and Attitudes. Londres: Appleton Century.

Umbreit, M., \& R. Coates (2000). Implicaciones multiculturales de justicia restaurativa: escollos potenciales y peligros. Washington (D.C.): Departamento de Justicia de EUA, Oficina de programas de Justicia y Oficina para las Víctimas del Crimen.

Uribe, C. (2011). Interdisciplinariedad en investigación: ¿colaboración, cruce o superación de las disciplinas? Bogotá: PUJ.

Ury, W., Fisher, R., \& Patton B. (1995). Sí...de acuerdo! Cómo negociar sin ceder. Bogotá: Norma.

Van Ness, D., \& Heetderks, K. (2015). A Brief History of Restorative Justice: The Development of a New Pattern of Thinking. En D. Van Ness \& K. Heetderks (Eds.) Restoring Justice (Fifth Edition) (pp. 23-41) EE.UU.: Routledge.

Velásquez, F. (2010). La Justicia Negociada: Un ejemplo del peligro de la privatización del proceso penal con el nuevo sistema. En F. Velásquez (Comp.), Sistema Penal Acusatorio y nuevos retos (pp. 13-42). Bogotá: Fondo de Publicaciones Universidad Sergio Arboleda.

Watzlawick, P., Beavin, J., \& Jackson, D. (1985). Teoría de la comunicación humana. Interacciones, patologías y paradojas. Barcelona: Herder.

Wechsler, D. (1940). Non-intellective factors in general intelligence. Psychological Bulletin, 37, 444-445.

Wexler, D., \& Winick, B. (2005). Justicia Terapéutica: una visión general. EEUU: Universidad de Arizona.

Winslade, J. (2013). Welcome letter. Narrative and conflict: Explorations in Theory and Practice, 1(1), 1-3.

Zehr, H. (2007). El pequeño libro de la Justicia Restaurativa. Estados Unidos: Good Books. 